University of Wollongong

Research Online

Faculty of Law, Humanities and the Arts Papers (Archive)

$1-1-2012$

The challenge of reducing greenhouse gas emissions from international shipping: assessing the international maritime organization's regulatory response

Yubing Shi

University of Wollongong, ys811@uowmail.edu.au

Follow this and additional works at: https://ro.uow.edu.au/lhapapers

Part of the Arts and Humanities Commons, and the Law Commons

Research Online is the open access institutional repository for the University of Wollongong. For further information contact the UOW Library: research-pubs@uow.edu.au 


\title{
The challenge of reducing greenhouse gas emissions from international shipping: assessing the international maritime organization's regulatory response
}

\author{
Abstract \\ As a comparatively cost effective, clean, and safe method of transportation, international shipping offers \\ an important means of moving goods internationally and enables other activities such as leisure \\ cruising. 1 Many factors contribute to the development of international shipping. As an example, the \\ evolution of ship propulsion has progressed from sailing ships to steam ships powered by coal and then \\ to an almost universal use of diesel engines, significantly accelerating international trade.2 Similarly, \\ advances in telecommunication and information and communications technology infrastructure, \\ reductions in trade barriers, and low energy costs have also contributed to the expansion of international \\ shipping and seaborne trade. 3 However, the increase in fuel consumption associated with increasing \\ seaborne trade has led to a rise in atmospheric emissions from international shipping.

\section{Keywords} \\ shipping, challenge, assessing, reducing, maritime, organization, regulatory, response, greenhouse, gas, \\ emissions, international

\section{Disciplines} \\ Arts and Humanities | Law

\section{Publication Details} \\ Y. Shi, 'The challenge of reducing greenhouse gas emissions from international shipping: assessing the \\ international maritime organization's regulatory response' (2012) 23 (1) Yearbook of International \\ Environmental Law 131-157.
}




\section{The Challenge of Reducing Greenhouse Gas Emissions from International Shipping: Assessing the International Maritime Organization's Regulatory Response}

Yubing Shi

\section{INTRODUCTION}

As a comparatively cost effective, clean, and safe method of transportation, international shipping offers an important means of moving goods internationally and enables other activities such as leisure cruising. ${ }^{1}$ Many factors contribute to the development of international shipping. As an example, the evolution of ship propulsion has progressed from sailing ships to steam ships powered by coal and then to an almost universal use of diesel engines, significantly accelerating international trade. ${ }^{2}$ Similarly, advances in telecommunication and information and communications technology infrastructure, reductions in trade barriers, and low energy costs have also contributed to the expansion of international shipping and seaborne trade. ${ }^{3}$ However, the increase in fuel consumption associated with increasing seaborne trade has led to a rise in atmospheric emissions from international shipping.

Emissions from international shipping, in particular greenhouse gas (GHG) emissions, have contributed to climate change. The 2007 Intergovernmental Panel on Climate Change's fourth assessment report states that 'most of the observed increase in global average temperatures since the mid- $20^{\text {th }}$ century is very likely due to the observed increase in

The author would like to thank Robin Warner and Warwick Gullett for their valuable comments on earlier drafts. However, the author takes full responsibility for the content of the article.

${ }^{1}$ International Maritime Organization (IMO), Introduction to IMO $<$ http://www.imo.org/About/Pages/Default.aspx>; see also Rajiv Saxena, Overseas Shipping Made Cheaper 42(7) Industrial Engineer 24 (2010). But see Matthew Stibbe, Shipping Security: All at Sea? 3(2) Infosecurity Today 32 (2006). Stibbe asserts that marine terrorism makes the shipping costly.

${ }^{2}$ Sujith Kollamthodi et al, Greenhouse Gas Emissions from Shipping: Trends, Projections

${ }^{3}$ Ibid. and Abatement Potential: Final Report, at 3 (2008). 
anthropogenic GHG concentrations. ${ }^{4}$ Global warming serves as the main manifestation of climate change. It is axiomatic that GHG emissions are one of the main contributions to global climate change.

Currently, seven types of GHGs are listed in the Kyoto Protocol to the UN Framework Convention on Climate Change (UNFCCC), namely carbon dioxide, methane, nitrous oxide, hydrofluorocarbons (HFC), perfluorocarbons (PFC), sulphur hexafluoride, and nitrogen trifluoride. ${ }^{5}$ The GHG emissions from international shipping mainly constitute carbon dioxide, methane, nitrous oxide, and HFC. ${ }^{6}$ Their total amount has been increasing too rapidly in recent years to be ignored. The International Maritime Organization's (IMO) second study on GHGs in 2009 states that in 2007 carbon dioxide emissions from international shipping reached 870 million tonnes, which covers 2.7 percent of the global emissions of carbon dioxide. ${ }^{7}$ Furthermore, mid-range emission scenarios indicate that by 2050, if no aggressive emission-reduction strategies are introduced, ${ }^{8}$ carbon dioxide emissions from international shipping may grow by a factor of two to three (compared with the emissions in 2007) due to the growth in shipping. ${ }^{9}$ These statistics and scenarios show that the increasing trend of GHG emissions from international shipping will be maintained in the long term and should be recognized as a growing problem among scientists, industry, and environmental policy makers.

${ }^{4}$ Intergovernmental Panel on Climate Change (IPCC), Fourth Assessment Report, Synthesis Report, 36 (2007), $<$ http://www.ipcc.ch/publications_and_data/ar4/syr/en/contents.html>.

${ }^{5}$ Kyoto Protocol, 37 ILM 32 (1998), Annex A. UN Framework Convention on Climate Change, 31 ILM 849 (1992) [UNFCCC]. The 1998 Kyoto Protocol only lists six types of GHGs, but a seventh type of GHG, nitrogen trifluoride, was added to the category in the Doha Climate Change Conference in 2012. Doha Amendment to the Kyoto Protocol, Decision 1/CMP.8, C.N.718.2012.TREATIES-XXVII.7.c (8 December 2012) (not yet in force).

${ }^{6}$ O Buhaug et al, Second IMO GHG Study 2009, Executive summary, 3 (2009).

${ }^{7}$ Ibid. These data have been criticized since they do not take account of the global economic downturn since 2009. To provide a better foundation for IMO's future work, an update of the 2009 IMO study of greenhouse gas (GHG) emissions estimate from international shipping is currently being carried out, and the final report is expected to be submitted to the IMO in 2014. Report of the Expert Workshop on the Update of GHG Emissions Estimate for International Shipping (Update-EW), note by the Secretariat, MEPC $65^{\text {th }}$ Session, Agenda Item 5, Doc MEPC 65/5/2 (4 March 2013).

${ }^{8}$ Ibid; N Nakicenovic et al, Special Report on Emissions Scenarios (2000). The scenarios are primarily based on assumptions of global development in the International Panel on Climate Change's (IPCC) Special Report on Emissions Scenarios storylines.

${ }^{9}$ Buhaug et al, supra note 6 at 1 . 
The problem of GHG emissions from international shipping is an issue of international dimension. To unite the international community in addressing this issue jointly, the United Nations has made active institutional and legal responses. The UNFCCC and its Kyoto Protocol, together with its Subsidiary Body on Scientific and Technological Advice (SBSTA), the Ad Hoc Working Group on Long-Term Cooperative Action (AWG-LCA), Conference of the Parties (COP), and the Conference of the Parties serving as the Meeting of the Parties to the Kyoto Protocol (CMP), have contributed to the international attempts to address the issue, although the effectiveness of their efforts has been questioned. ${ }^{10}$ As a consequence, GHG emissions from international shipping are not regulated by the UNFCCC and its Kyoto Protocol. ${ }^{11}$

As a specialized agency of the United Nations, the IMO has recognized the problem of GHG emissions from ships and has acted on it based on Article 2(2) of the Kyoto Protocol as well as on the Convention on the International Maritime Organization (IMO Convention) and the United Nations Convention on the Law of the Sea (UNCLOS). ${ }^{12}$ In contrast to the efforts made within the UN international climate change regime, there are high expectations of the IMO due to its mandate and strength in regulating GHG emission-related technical matters. In particular, the newly adopted revised Annex VI of the International Convention for the Prevention of Pollution from Ships (MARPOL Convention) ${ }^{13}$ and the guidelines

${ }^{10}$ See, eg, Sebastian Oberthür, Institutional Interaction to Address Greenhouse Gas Emissions from International Transport: ICAO, IMO and the Kyoto Protocol 3(3) Climate Policy 191, 193 (2003). Oberthür asserts that parties to the UNFCCC had wide discussions on the GHG emissions from international transport, and its SBSTA has been working on marine bunker fuels. However, under the UNFCCC process, no regulation on shipping GHGs has been achieved. However, see, Bernd Hackmann, Analysis of the Governance Architecture to Regulate GHG emissions from International Shipping 12(1) Int'l Envt'l Agreements: Politics, Law \& Economics 85, 90 (2012). Hackmann claims that the work by the UNFCCC on the issue is still proceeding, and regulating shipping GHG emissions should fall under the scope of the Bali Action Plan.

${ }^{11}$ The UNFCCC only requires the regulation of national reduction of GHG emissions from ships, while the Kyoto Protocol requires the IMO to regulate GHG emissions from international shipping. UNFCCC, supra note 5, Article 4(1)(c); Kyoto Protocol, supra note 5, Article 2(2).

${ }^{12}$ A detailed discussion on this issue is provided in the next section. Convention on the InterGovernmental Maritime Consultative Organization, opened for signature 6 March 1948, 289 UNTS 3, amended and renamed as Convention on the International Maritime Organization, 9 UTS 61 [IMO Convention].

${ }^{13}$ International Convention for the Prevention of Pollution from Ships, 12 ILM 1319, as amended by the 1978 Protocol to the 1973 Convention, 1341 UNTS 3, 17 ILM 546 [MARPOL Convention]. To date, the MARPOL Convention has adopted six annexes 
produced by the IMO have assured the international community of progress regarding the adoption of energy-efficiency measures. Since these outcomes have been achieved since July 2011, there has not been much scholarly analysis on these rules as yet. Current discussions mainly focus on the institutional interaction ${ }^{14}$ between the IMO, the UNFCCC, and the International Civil Aviation Organization (ICAO), as well as the proposed market-based measures (MBMs) in relation to the reduction of GHG emissions from ships. ${ }^{15}$ This article conducts a comprehensive analysis of the IMO's efforts in regulating these issues.

The first part of this article looks briefly at the IMO's mandate for regulating shipping GHG emissions. Having established the central role of the IMO in providing a solution to the problem, the article then examines and assesses the IMO GHG regime from three perspectives, namely the evolution of the regime, Annex VI and its amendments to the MARPOL Convention, and the main outcomes achieved within the IMO.

II. IMO'S MANDATE TO REGULATE GHG EMISSIONS FROM INTERNATIONAL SHIPPING AND THE APPLICABLE PRINCIPLES

and their revisions, namely, Annex I on Oil (entered into force 2 October 1983); Annex II on Noxious Liquid Substances Carried in Bulk (entered into force 6 April 1987); Annex III on Harmful Substances Carried in Packaged Form (entered into force 1 July 1992); Annex IV on Sewage (entered into force 27 September 2003); Annex V on Garbage (entered into force 31 December 1988); and Annex VI on Air Pollution from Ships (entered into force 19 May 2005).

${ }^{14}$ See, eg, Lindsey Wuisan, Judith Van Leeuwen, and CSA Van Koppen, Greening International Shipping through Private Governance: A Case Study of the Clean Shipping Project 36(1) Marine Policy 165 (2012); Hackmann, supra note 10; Sebastian Oberthür, The Climate Change Regime: Interactions with ICAO, IMO, and the EU Burden-Sharing Agreement, in Sebastian Oberthür and Thomas Gehring (eds), Institutional Interaction in Global Environmental Governance, 53 (2006); Oberthür, supra note 10.

${ }^{15}$ See, eg, Harilaos N Psaraftis, Market-based Measures for Greenhouse Gas Emissions from Ships: A Review 11(2) WMU Journal of Maritime Affairs 211 (2012); Henrik Ringbom, Global Problem--Regional Solution? International Law Reflections on an EU CO $\mathrm{O}_{2}$ Emissions Trading Scheme for Ships 26(4) Int'1 J Marine \& Coastal L 613 (2011); Md Saiful Karim and Shawkat Alam, Climate Change and Reduction of Emissions of Greenhouse Gases from Ships: An Appraisal 1(1) Asian J Int'1 L 131 (2011); Jodie Moffat, Arranging Deckchairs on the Titanic: Climate Change, Greenhouse Gas Emissions and International Shipping 24(2) Australian \& New Zealand Maritime LJ 104 (2010). 
To cope with the increasingly serious issues of safety at sea and marine pollution, ${ }^{16}$ the United Nations Maritime Conference was held in Geneva on 6 March 1948. This conference adopted a convention that formally established the Inter-Governmental Maritime Consultative Organization (IMCO), which subsequently changed name to the IMO in May 1982. ${ }^{17}$ Article 1 of the IMO Convention outlines five purposes of the organization, which can be broadly summarized into its jurisdiction on technical and commercial matters such as discriminatory practices by shipping companies. Due to the possible threat to the practice of free enterprise in the shipping industry from the commercial jurisdiction of the IMO, many states have attempted to limit the purposes of the IMO to technical aspects rather than commercial regulation. Consequently, the IMO has focused primarily on its technical jurisdiction. ${ }^{18}$ Therefore, the main purpose of the IMO is 'to encourage the general adoption of the highest practicable standards in matters concerning maritime safety, efficiency of navigation and the prevention and control of marine pollution from ships. ${ }^{19}$

The IMO's structure has developed, reflecting its evolving mandate. ${ }^{20}$ Initially, the IMO only comprised the Assembly, the Council, and the Maritime Safety Committee (MSC).$^{21}$ Currently, the IMO consists of an Assembly, a Council, and five main Committees: the MSC, the Marine Environment Protection Committee (MEPC), the Legal Committee, the Technical Co-operation Committee, and the Facilitation Committee. Among these, the MEPC, which comprises all member states, is responsible for the reduction of GHG emissions from international shipping. In addition, the inter-sessional meeting of the IMO's Working Group on GHG Emissions from Ships (GHG-WG) was established between two MEPC sessions. These changes indicate the growing significance of marine environmental protection and co-operation among various institutions. $^{22}$

${ }^{16}$ GP Pamborides, International Shipping Law: Legislation and Enforcement, at 79-80 (1999).

${ }^{17}$ IMO Convention, supra note 12.

${ }^{18}$ To date, the IMO has never been allowed to exercise its full economic mandate. Alan Khee-Jin Tan, Vessel-Source Marine Pollution: The Law and Politics of International Regulation, at 75 (2006); see also Pamborides, supra note 16 at 83.

${ }^{19}$ IMO Convention, supra note 12, Article 1(a).

${ }^{20}$ Tan, supra note 18 at 76.

${ }^{21}$ Lawrence Juda, IMCO and the Regulation of Ocean Pollution from Ships 26(3) Int'1 \& Comparative LQ 558, 559 (1977).

${ }^{22}$ For instance, the establishment of the Facilitation Committee is to harmonize shipping procedures and eliminate unnecessary formalities and 'red tape' in international shipping. Tan, supra note 18 at 76. 
Currently, there are two views concerning the IMO's mandate in regulating GHG emissions from international shipping. One view is that the IMO's mandate comes from the Kyoto Protocol. ${ }^{23}$ Article 2(2) of the Kyoto Protocol requests the Annex I states of the UNFCCC to 'work through the IMO' to limit or reduce their shipping GHG emissions. Additionally, the acceptance of this mandate by the IMO also complies with the IMO Convention. ${ }^{24}$ However, this authorization was given to the IMO only after the UNFCCC failed to reach consensus on the allocation of such emissions among different states. ${ }^{25}$ In other words, at that time, the IMO was generally regarded as the most competent international organization to regulate this issue. The other view attributes the IMO's mandate on this issue to the IMO Convention and UNCLOS on the grounds that Articles 1(a) and 59 of the IMO Convention and Articles 211 and 212 of the UNCLOS provide the IMO with such competence. ${ }^{26}$ However, both views have their legal bases, and it is open to debate which rules should prevail if there is a conflict between the Kyoto Protocol, the IMO Convention, and the UNCLOS on the issue. In this case, it might be appropriate to strike a compromise between both views. Or to be more specific, the IMO Convention and the UNCLOS provide the IMO with general competence to regulate this type of issue, while the Kyoto Protocol provides the IMO with a specific mandate in regulating this matter.

${ }^{23}$ See, eg, Haifeng Wang, GHG Emissions from the International Goods Movement by Ships and the Adaptation Funding Distribution, in Zongwei Luo (ed), Green Finance and Sustainability: Environmentally-Aware Business Models and Technologies, 274 at 275 (2011).

${ }^{24}$ IMO Convention, supra note 12, Article 68.

${ }^{25}$ Since 1995, when the first Conference to the Parties (COP-1) to the UNFCCC was held, the SBSTA within the UNFCCC has been working on the possible inclusion of GHG emissions from international shipping into the Kyoto Protocol. In 1996, the SBSTA selected five options from eight choices as the basis for discussing the possible allocation of emissions among different states but failed in reaching consensus. Due to the highly technical and international character of the shipping industry, the UNFCCC finally decided to turn the issue to the IMO. Article 2(2) of the Kyoto Protocol formally excludes the regulation of GHG emissions from international shipping from the Kyoto Protocol, while emissions from domestic shipping are still included in national targets for Annex I states. See Possible Revisions to the Guidelines for the Preparation of National Communications by Parties Included in Annex I to the Convention, SBSTA $4^{\text {th }}$ Session, Doc UNFCCC/SBSTA/1996/9/Add.1 (24 October 1996) 11; Karim and Alam, supra note 15 at 134; Oberthür, supra note 10 at 193.

${ }^{26}$ This opinion has been held by the Sub-Division for Legal Affairs within the IMO. See also, eg, Karim and Alam, supra note 15 at 147-48; Oberthür, supra note 10 at 195. 
Seen in this way, the two views are not conflicting. This approach is underpinned by the newly adopted revised Annex VI to the MARPOL Convention. The preamble of Annex VI provides:

Recognizing also that adoption of the amendments to Annex VI in no way prejudges the negotiations held in other international fora, such as the United Nations Framework Convention on Climate Change (UNFCCC), nor affect the positions of the countries that participate in such negotiation. ${ }^{27}$

This expression appears to represent the IMO's view on this issue. That is, regarding the decisions on GHG emissions from ships, those made by the IMO, including the revised Annex VI, are independent from those reached within the UNFCCC/Kyoto Protocol regime. Nevertheless, as an obligation under the Kyoto Protocol, the IMO needs to report its progress on this issue to the UNFCCC on a regular basis. ${ }^{28}$ Based on the earlier approach, it might be deduced that theoretically both the common but differentiated responsibility (CBDR) principle (from the UNFCCC) and the no more favourable treatment (NMFT) principle (from the IMO) should be applied to the issue under discussion. To better understand this view, a general background on the two principles is provided.

The CBDR principle requires both developed and developing states to contribute to addressing environmental problems and imposes the primary responsibility on developed states due to their different historical contributions to the problems and the differentiated capability of developed and developing states. It can be traced back to the 1972 Stockholm Conference on the Human Environment, when the concept of sustainable development was first raised and the different development priorities of developed countries and developing countries were identified. ${ }^{29}$ Thus, the Stockholm conference represented 'the first time that an international consensus had been reached, at least in theory, on applying CBDR and differentiated standards to international environmental problems. ${ }^{30}$ This principle was

${ }^{27}$ MARPOL Convention, supra note 13, Annex VI, preamble [emphasis added].

${ }^{28}$ Within the IMO, the MEPC reports any progress relating to GHG emissions from international shipping to the Council of the IMO, while the IMO provides regular progress reports to the SBSTA within the UNFCCC.

${ }^{29}$ See, eg, Nina E Bafundo, Compliance with the Ozone Treaty: Weak States and the Principle of Common but Differentiated Responsibility 21(3) Am U Intl L Rev 461 at 468 (2006).

${ }^{30}$ Michael Weisslitz, Rethinking the Equitable Principle of Common but Differentiated Responsibility: Differential versus Absolute Norms of Compliance and Contribution 
implicit in the 1987 Montreal Protocol on Substances That Deplete the Ozone Layer to the Vienna Convention for the Protection of the Ozone Layer ${ }^{31}$ and first explicitly formulated in Principle 7 of the Rio Declaration on Environment and Development. ${ }^{32}$ To date, it has been widely accepted and endorsed by many conventions and treaties, including the 1992 Convention on Biological Diversity (CBD), ${ }^{33}$ the 1992 UNFCCC, and its Kyoto Protocol. ${ }^{34}$

The NMFT principle refers to "port States enforcing applicable standards in a uniform manner to all ships in their ports, regardless of flag. ${ }^{35}$ Article 3 of the IMO Convention treats the 'normal processes of international shipping business' as a prior way for the IMO to deal with shipping related matters, which indeed provides a legal basis for the NMFT principle. The term NMFT was included in the MARPOL Convention and applies to all of the annexes of the convention. ${ }^{36}$ So far, this policy has been consistent without exception among all fiftythree IMO treaty instruments currently in existence.

Given that the CBDR principle runs through the Kyoto Protocol, ${ }^{37}$ it could be construed that the authorization of the IMO's mandate from the Kyoto Protocol indicates that the CBDR principle should also apply to the reduction of GHG emissions from ships.

Nevertheless, in practice, developed countries generally insist on the application of the NMFT principle to this issue, while developing countries back the CBDR principle. ${ }^{38}$ It

in the Global Climate Change Context 13(2) Colorado J Int'1 Envt'1 Law \& Policy 473 at 480 (2002).

${ }^{31}$ Montreal Protocol on Substances That Deplete the Ozone Layer, 26 ILM 1550, Article 5. This protocol requires both developed countries and developing countries to work together to reduce controlled substances but provides developing countries with a tenyear grace period. This practice is consistent with the principle of common but differentiated responisbility (CBDR), but the term of the CBDR was not put forward with explicit explanation. Vienna Convention on the Protection of the Ozone Layer, 1513 UNTS 323 [Vienna Convention].

${ }^{32}$ Rio Declaration on Environment and Development, 31 ILM 874 (1992), Principle 7 [Rio Declaration].

${ }^{33}$ Convention on Biological Diversity, 31 ILM 818 (1992), Article 20(4) [CBD].

${ }^{34}$ UNFCCC, supra note 5, Article 3-4; Kyoto Protocol, supra note 5, Article 10.

${ }^{35}$ Buhaug et al, supra note 6 at 20.

${ }^{36}$ MARPOL Convention, supra note 13, Article 5(4) stipulates that, '[w]ith respect to the ship of non-PArticleies to the Convention, PArticleies shall apply the requirements of the present Convention as may be necessary to ensure that no more favourable treatment is given to such ships' [emphasis added].

${ }^{37}$ Kyoto Protocol, supra note 5, Article 10.

${ }^{38}$ See, eg, the United States, Spain, and Sweden underscore the application of the no more favourable treatment (NMFT) principle to this issue, whereas China, India, Brazil, Saudi Arabia, and Peru support the application of the CBDR principle. Report of the Marine Environment Protection Committee on Its Sixtieth Session, MEPC $60^{\text {th }}$ Session, Agenda Item 22, Doc MEPC 60/22 (12 April 2010), Annex 4. 
seems this conflict can be resolved if both the principles apply to the issue, and this approach has been accepted by UNFCCC Secretariat ${ }^{39}$ as well as by some states and non-governmental organizations (NGOs). ${ }^{40}$ Is it feasible for the IMO to apply both the CBDR principle and the NMFT principle when it utilizes its competence to address the GHG emissions from ships? Probably, the key lies in the appropriate interpretation of 'differentiated responsibility' under the CBDR principle. Current international environmental agreements indicate that the differentiated responsibility consists of three categories, namely differentiated central obligations, differentiated implementation arrangements, and the granting of assistance including financial and technological assistance. ${ }^{41}$ To reach acceptable methods of applying the CBDR principle in reducing shipping GHG emissions by both developed and developing countries is quite possible, provided the interests of the various stakeholders are taken into consideration and well balanced. Although the CBDR principle was not fully incorporated in the energy efficiency measures recently adopted by the IMO, some of the proposed MBMs do apply the CBDR principle. Further discussion of these issues is contained in the following sections.

\section{THE IMO GHG EMISSIONS REGIME}

The IMO has partially regulated GHG emissions from international shipping by means of various negotiations and discussions within its MEPC. The conventions, codes, resolutions, and various discussions achieved or conducted during this process constitute the IMO regime on the reduction of shipping GHG emissions or, in other words, the IMO GHG emissions regime. This part of the article first reviews the development of this regime and then examines Annex VI to the MARPOL Convention and its amendments-the major

${ }^{39}$ Report of the Marine Environment Protection Committee on Its Sixty-First Session, MEPC $61^{\text {st }}$ Session, Agenda Item 24, Doc MEPC 61/24 (6 October 2010), Annex 6, 2. At the sixty-first MEPC meeting, the UNFCCC Secretariat made a statement, which asserts that '[w]e have to commit ourselves to work on a solution which respects both principles, and allows each treaty regime to retain the integrity of its principles and practices.'

${ }^{40}$ See, eg, Malaysia and the World Wide Fund for Nature (WWF) support the application of the two principles to the issue. Report of the Marine Environment Protection Committee on Its Sixtieth Session, MEPC $60^{\text {th }}$ Session, Agenda Item 22, Doc MEPC 60/22 (12 April 2010), Annex 4, 10; Ensuring No Net Incidence on Developing Countries from a Global Maritime Market-Based Mechanism, submitted by WWF, IMO Doc MEPC 63/5/6 (22 December 2011).

${ }^{41}$ Lavanya Rajamani, Differential Treatment in International Environmental Law, at 191 (2006). 
achievement of this regime to date. Finally, the outcomes within the MEPC are summarized and analysed.

\section{Evolution of the IMO GHG Emissions Regime}

Although discussions on GHG emissions from ships within the IMO started in the late 1980s, it is generally accepted that the IMO's work on this issue formally commenced in $1997 .{ }^{42}$ During that year, the MARPOL Conference not only adopted a protocol on Annex VI to the MARPOL Convention but also adopted Resolution 8 on "carbon dioxide emissions from ships,' which requested the IMO to undertake a study on GHG emissions from ships and consider feasible carbon dioxide reduction strategies. ${ }^{43}$ Following joint efforts by several internationally renowned research institutes, a study of GHG emissions from ships was published in $2000 .^{44}$ This study not only answered the question of why GHG emissions from shipping should be reduced, but it also explored how to deal with the issue. It canvassed the reduction potential of different technical, operational, and market-based approaches, which to some extent provide a 'road map' for future policies within the IMO. In 2003, a resolution was adopted by the IMO Assembly on 'IMO policies and practices related to the reduction of greenhouse gas emissions from ships,' urging the MEPC to 'identify and develop the mechanism or mechanisms needed to achieve the limitation or reduction of GHG emissions from international shipping. ${ }^{45}$ Since then, the MEPC has been working on this issue by means of various negotiations and discussions within its series of session meetings as well as in its GHG-WGs.

The evolution of the IMO GHG emissions regime has been lengthy and intermittent. During a fourteen-year period from September 1997 to July 2011, no binding agreements regarding GHG emissions from international shipping were reached within the IMO, and

${ }^{42} \mathrm{IMO}$, Main Events in IMO's Work on Limitation and Reduction of Greenhouse Gas Emissions from International Shipping (2011), $<$ http://www.imo.org/MediaCentre/resources/Pages/Greenhouse\%20gas\%20emission ${ }^{43}$ Ibid. s.aspx $>3$.

${ }^{44}$ These institutes were from Norway and the United States, namely MARINTEK (Norway), Det Norske Veritas (Norway), ECON, Center for Economic Analysis (Norway), and Carnegie Mellon University (United States). Kjell Skjølsvik et al, Study of Greenhouse Gas Emissions from Ships, at 7 (2000).

${ }^{45}$ Resolution A.963(23) on IMO Policies and Practices Related to the Reduction of Greenhouse Gas Emissions from Ships, IMO Assembly $23^{\text {rd }}$ Session, Agenda Item 19 (5 December 2003). 
producers of emissions were exempt from liabilities under this regime. On 15 July 2011, shipping GHG emissions were partially regulated by technical and operational measures. Intensive discussions on this issue have only occurred since 2008. During this process, the IMO reiterated at least three times its role as the most competent international body in regulating GHG emissions from shipping. This claim might have resulted from competitive institutional pressure from other international organizations such as the UNFCCC and the possibility of unilateral measures being adopted by individual states and the European Union (EU). ${ }^{46}$ It has been generally accepted that the measures tackling shipping GHG emissions can be classified into technical measures, operational measures, and MBMs. Concerning the technical and operational measures, the IMO is the only competent international body governing the issue. The IMO has been mandated to regulate technical matters on shipping, and currently no other international body possesses the IMO's technical expertise. In practice, the global shipping industry, ${ }^{47}$ including national shipping industries from the UNFCCC's non-Annex I states, ${ }^{48}$ takes the view that the IMO is the only competent organization to regulate the issue from a technical and operational perspective. Against this backdrop, technical and operational measures have been regulated by the IMO in the form of energy efficiency measures under the revised Annex VI of the MARPOL Convention in July 2011. However, this may not be the case in the future regulation of MBMs. Since some MBM options involve out-of-sector emission reductions and international trade that are beyond the competence of the IMO, it is possible that a working group between the IMO and the

${ }^{46}$ See Oberthür, supra note 10 at 202-3.

${ }^{47}$ For instance, the four Round Table members, namely the International Chamber of Shipping (ICS), the Baltic and International Maritime Council (BIMCO), the International Association of Independent Tanker Owners (INTERTANKO) and the International Association of Dry Cargo Shipowners (INTERCARGO), asserted that both technical and operational measures and market-based measures (MBMs) should be governed by the IMO. Future IMO Regulation Regarding Greenhouse Gas Emissions from International Shipping, submitted by Denmark, Marshall Islands, BIMCO, ICS, INTERCARGO, INTERTANKO, and OCIMF, MEPC $57^{\text {th }}$ Session, Agenda Item 4, Doc MEPC 57/4/2 (21 December 2008) at para 10; Round Table of International Shipping Associations, Round Table Associations Position Paper on $G H G+M B M s$ (22 February 2012), $<$ https://www.bimco.org/About/Press/Press_Releases/2012/2012_02_22_Round_Tabl e_MBM.aspx>.

${ }^{48}$ For instance, China's shipping industry generally supports the IMO's role in regulating technical and operational measures to tackle shipping GHG emissions. Wang Erde, 'Consensus Achieved by Reduction Negotiations and China Is to Start Its Reduction in 2019,' Twenty-First Century Business Herald (Beijing), 6 July 2011, $<$ http://stock.sohu.com/20110726/n314586469.shtml>. 
UNFCCC or the World Trade Organization (WTO) could be established to collaborate in addressing this issue. In fact, some UNFCCC non-Annex I states such as China, India, and Malaysia doubt the competence of the IMO in regulating MBMs and assert that MBMs should be determined by the UNFCCC. ${ }^{49}$

The debate on the incorporation of either the CBDR principle or the NMFT principle into the reduction of GHG emissions from ships has run through all of the negotiations and discussions within the IMO. The conflict of the two principles has delayed the advancement of the negotiations within the MEPC. ${ }^{50}$ To expedite the negotiation process within the MEPC, the fifty-second MEPC meeting adopted a two-step strategy, according to which the MEPC was to deal with all of the technical matters related to GHG limitations or reductions first and then resolve the politically related issues including the application of the CBDR or NMFT principles. ${ }^{51}$ However, it has been difficult to separate the two steps. In 2008, the fiftyseventh MEPC meeting adopted nine fundamental principles as a basis for future regulations, although they were opposed by many developing countries. Principle 2 provides that the future IMO framework should be 'binding and equally applicable to all flag States in order to avoid evasion, ${ }^{52}$ which incorporates the NMFT principle. The fifty-eighth MEPC meeting in 2008 discussed a proposed change to Principle 2, which was amended to read that it was, 'binding and equally applicable to all ships, without this requiring States to accept similar regulations/standards in other fora. ${ }^{53}$ In this case, the responsible entity shifts from flag states to all ships and the application of this principle is limited to either the MEPC or the IMO. However, the NMFT principle remained in this version, and, consequently, no consensus was achieved. As to the proposed MBMs, the application of the CBDR or the NMFT principle has been the main focus of debate, which can be seen from the succeeding rounds of negotiations. It is concluded that the evolution of the IMO GHG emissions regime is a process where various technical and operational measures and MBMs have been

${ }^{49}$ Report of the Marine Environment Protection Committee on Its Sixtieth Session, MEPC $60^{\text {th }}$ Session, Agenda Item 22, Doc MEPC 60/22 (12 April 2010), Annex 4, 2, 8, 10.

${ }^{50}$ See Hackmann, supra note 10 at 96.

${ }^{51}$ Report of the Marine Environment Protection Committee on Its Fifty-Second Session, MEPC 52 ${ }^{\text {nd }}$ Session, Agenda Item 24, Doc MEPC 52/24 (18 October 2004) at para 4.35 .

${ }^{52}$ Report of the Marine Environment Protection Committee on Its Fifty-Seventh Session, MEPC 57 $7^{\text {th }}$ Session, Agenda Item 21, Doc MEPC 57/21 (7 April 2008) at para 4.73.

${ }^{53}$ Identifying Consensus on IMO Principles on Addressing Greenhouse Gas Emissions from International Shipping, submitted by Australia, Canada, Denmark, Germany, Japan, Marshall Islands, Norway, Panama, and the United States, MEPC $58^{\text {th }}$ Session, Agenda Item 4, Doc MEPC 58/4/16 (1 August 2008) at para 5. 
discussed and negotiated in an attempt to reach agreement between developed and developing countries. To date, this regime is still under development; however, some outcomes, including the newly amended Annex VI and some guidelines, have been achieved within the MEPC. ${ }^{54}$

\section{Annex VI to the MARPOL Convention and Its Amendments}

As a means of reducing shipping GHG emissions, technical and operational measures were raised and examined in the report entitled Study of Greenhouse Gas Emissions from Ships in 2000 (the first IMO GHG study). Based on both a short-term and long-term perspectives, the report classifies carbon dioxide reduction potential by technical measures into two categories: measures for new ships and measures for existing ships. ${ }^{55}$ It identifies various technical and operational measures and concludes that these measures have a limited potential for reducing shipping emissions, and it might be 'more feasible' for the shipping industry to implement these measures primarily through new ship construction. ${ }^{56}$ The second IMO GHG study in 2009 emphasizes the role of new ship construction in increasing efficiency and reducing emissions and proposes a mandatory energy efficiency design index (EEDI) for new ships as an incentive to improve the design efficiency of these ships. ${ }^{57}$ Based on this work and on intensive discussions and negotiations on various technical, operational, and market-based measures within the IMO, the sixty-second MEPC meeting adopted the revised Annex VI to the MARPOL Convention on 15 July 2011. This amendment represents 'the first ever mandatory global [and legally binding] GHG reduction regime for an international industry sector. ${ }^{58}$ Since that time, GHG emissions from shipping have been partially regulated. However, this amendment to Annex VI only regulates a package of mandatory technical and operational measures to reduce GHG emissions from international shipping. By adding a new Chapter 4 to Annex VI on the regulation on energy efficiency for ships, the amendment

\footnotetext{
${ }^{54}$ These outcomes include the amended MARPOL Convention, supra note 13, Annex VI, adopted on 15 July 2011, and four guidelines, adopted in 2 March 2012. See note 75 in this article.

${ }^{55}$ Kjell Skjølsvik et al, supra note 44 at 14.

${ }^{56}$ Ibid at 8-9.

${ }^{57}$ Buhaug et al, supra note 6 at 1 . The report concludes that if technical and operational measures are implemented together, 'these measures could increase efficiency and reduce the emissions rate by $25 \%$ to $75 \%$ below the current levels.'

${ }^{58}$ IMO, Mandatory Energy Efficiency Measures for International Shipping Adopted at IMO Environment Meeting, <http://www.imo.org/MediaCentre/PressBriefings/Pages/42mepc-ghg.aspx $>$.
} 
makes mandatory the EEDI for new ships and the Ship Energy Efficiency Management Plan (SEEMP) for all ships.

Due to the deadlock in the negotiations of the CBDR and NMFT principles within the IMO, a breakthrough on other measures including MBMs has not yet been achieved. The successful outcome on the technical and operational regulation can be attributed to the following two factors. First, the energy efficiency measures were included in the revised Annex VI rather than creating a new Annex VII to the MARPOL Convention. For this amendment to Annex VI, the 'tacit acceptance' procedure applied. According to this procedure, amendments of the MARPOL Convention annexes or appendices to such annexes enter into force on a specified date unless a specific number of state parties object by an agreed date. ${ }^{59}$ Due to the technical nature of these annexes and appendices, it might be inferred that the 'tacit acceptance' procedure basically applies to technical amendments. In this case, the 'silence' of a member state represents its approval and makes a formal acceptance unnecessary. ${ }^{60}$ This procedure, however, does not apply to either the articles of the convention or to the introduction of a new annex. ${ }^{61}$ The main benefit of the tacit acceptance' procedure lies in the expedited entry into force of the amendments. This procedure partially explains why these revisions entered into force on 1 January 2013 shortly after their adoption, despite the opposition of many developing countries. ${ }^{62}$ Second, the voting mechanism within the MEPC accelerates the adoption of these measures. Rule 27 of the Rules of Procedures of the MEPC provides that decisions of the committee and of its subsidiary bodies are made by a majority of the members present and voting rather than by a consensus. ${ }^{63}$ This policy ensures that a resolution can be adopted by the MEPC even if some countries with large owned fleets oppose it. To change this situation, many developing countries proposed at the sixty-fourth MEPC meeting that all decisions of the MEPC on GHG

\footnotetext{
${ }^{59}$ MARPOL Convention, supra note 13, Article 16.

${ }^{60}$ Pamborides, supra note 16 at 101.

${ }^{61}$ MARPOL Convention, supra note 13, Article 16(2)(f), 16(5).

${ }^{62}$ See, eg, Comments on the Proposed Mandatory Energy Efficiency Regulations, submitted by China, Saudi Arabia, and South Africa, Doc MEPC 62/5/10 (5 May 2011). The cosponsors of this proposal, namely China, Saudi Arabia, and South Africa, opposed the adoption of the amendment because of its exclusion of the CBDR principle, technical uncertainty, and other factors. They also opposed the inclusion of energy efficiency measures in MARPOL Annex VI due to the different nature of GHGs and other air pollutants.

${ }^{63}$ IMO, Basic Documents, volume 1, at 113 (2010).
} 
emissions from ships should be adopted by consensus, but the debate on this issue has been postponed until the sixty-fifth MEPC meeting in 2013 . $^{64}$

The energy efficiency measures apply to all ships of 400 gross tonnage and above. ${ }^{65}$ Due to the global financial crisis since 2009, this new regulation has imposed a great deal of pressure on global shipping industries, in particular, those from developing countries.

Nevertheless, under Regulation 19, there is flexibility in the application of the EEDI:

\section{Regulation 19}

1. This chapter shall apply to all ships of 400 gross tonnage and above ...

4. Notwithstanding the provisions of paragraph 1 of this regulation, the Administration may waive the requirement for a ship of 400 gross tonnage and above from complying with regulation 20 and regulation 21 .

5. The provision of paragraph 4 of this regulation shall not apply to ships of 400 gross tonnage and above:

1. for which the building contract is placed on or after 1 January 2017; or

2. in the absence of a building contract, the keel of which is laid or which is at a similar stage of construction on or after 1 July 2017; or

3. the delivery of which is on or after 1 July 2019; or

4. in cases of a major conversion of a new or existing ship, as defined in regulation 2.24, on or after 1 January 2017, and in which regulation 5.4.2 and regulation 5.4.3 of chapter 2 apply. [emphasis added]

Regulation 19.4 and 19.5 indicate that for some countries the actual commencement date of the EEDI might be postponed six and a half years from 1 January $2013 .{ }^{66}$ Since the administration is generally the flag state of a ship, ${ }^{67}$ this regulation gives the ships from developing countries a long lead time for their preparation and adjustment. This treatment is still non-differentiated between developed and developing countries and thus does not apply

${ }^{64}$ Further Work on GHG Emissions from Ships, submitted by Brazil, China, India, Peru, Saudi Arabia, and South Africa, MEPC $64^{\text {th }}$ Session, Agenda Item 5, Doc MEPC 64/5/9 (27 July 2012) at para 8.1.

${ }^{65}$ MARPOL Convention, supra note 13, Annex VI (2011), Regulation 19.1.

${ }^{66}$ Or such ships will be exempt of complying with EEDI until 1 January 2017 based on contract date. MARPOL Convention, supra note 13, Annex VI (2011), Regulation 19.5.2.

${ }^{67}$ MARPOL Convention, supra note 13, Article 2(5). 
the CBDR principle. ${ }^{68}$ In practice, this waiver might be used primarily by ships flying the flags of developing countries due to the much more stringent requirements by developed countries. Nevertheless, prior to the adoption of this amendment, Vanuatu submitted a proposal on possible exemptions from the EEDI requirements for ships trading to the least developed countries and small island developing states, but it was not accepted by the sixtyfirst MEPC meeting. ${ }^{69}$

In this sense, this waiver clause could be deemed to be a compromise between developed countries and developing countries. According to an assessment by Lloyd's Register and Det Norske Veritas, the impact of the waiver clause (Regulation 19.5) is estimated to be low on the total emission reduction potential. ${ }^{70}$ This is because low compliance costs and the commercial disadvantages associated with non-compliance make it unattractive for flag states or shipowners to opt for an EEDI waiver. ${ }^{71}$ Given the situations of the countries supporting this waiver clause, notably Brazil, China, and Saudi Arabia, the most likely level of waiver is only 5 percent. $^{72}$ To assist with the implementation of the mandatory

${ }^{68}$ This regulation was misinterpreted by some media and scholars as solely applying to the developing countries. See, eg, John Vidal, Maritime Countries Agree First Ever Shipping Emissions Regulation <http://www.guardian.co.uk/environment/2011/jul/18/maritime-countries-shippingemissions-regulation>; Laura Boone, Reducing Air Pollution from Marine Vessels to Mitigate Arctic Warming: Is it Time to Target Black Carbon? 1Carbon \& Climate Law Rev 13, 18 (2012). Vidal commented that 'China, Brazil, Saudi Arabia and South Africa have secured a six and a half year delay for new ships registered in developing countries.'

${ }^{69}$ Report of the Marine Environment Protection Committee on Its Sixty-First Session, MEPC $61^{\text {st }}$ Session, Agenda Item 24, Doc MEPC 61/24 (6 October 2010) at ss 5.32-5.33. Before the meeting, Vanuatu proposed to include a provision in the draft regulation on an exemption for these vessels trading to least developed countries and small island developing states (SIDS). However, the committee did not agree with the proposal on the grounds that the adoption of this provision could mean that 'the least efficient ships would serve these trades/routes indefinitely' and would prejudice the benefits of developing countries due to higher transportation costs resulted as such.

${ }^{70}$ Zabi Bazari and Tore Longva, Assessment of IMO Mandated Energy Efficiency Measures for International Shipping, Doc MEPC 63/INF.2, Annex (31 October 2011) at 6-7, Appendix 1, 3 .

${ }^{71}$ Ibid, Appendix 1, 1-3. Appendix 1 of the report analyses that technology cost of compliance to EEDI will be low due to such factors as EEDI reference lines, ship hydrodynamic optimization, and preparation for future more stringent Phases 2 and 3; and an EEDI non-compliance ship is projected to suffer from certain commercial costs including higher ship fuel cost, cost of re-verification, second hand value, opportunity costs, and charter-ability.

${ }^{72}$ Ibid. According to the report, these three countries supported the waiver clause at the sixtysecond MEPC meeting. If the waiver will be taken up by these countries, as of 
regulations on energy efficiency for ships in the 2011 Annex VI, the sixty-third MEPC meeting in March 2012 adopted four important guidelines. ${ }^{73}$ These guidelines, together with various technical, operational, and MBMs, are discussed in the next section.

\section{Outcomes within the MEPC}

Measures dealing with shipping GHG emissions generally can be classified into three categories: technical measures, operational measures, and MBMs. These measures have been widely discussed and negotiated within the MEPC since the adoption of Resolution 8 on 'carbon dioxide emissions from ships' in 1997. Currently, technical and operational measures are included in Annex VI to the MARPOL Convention in the forms of the EEDI and the SEEMP requirements respectively, whereas MBMs are still unregulated. This section introduces the newly adopted technical and operational measures, followed by an assessment on their benefits and deficiencies. It then provideds an analysis and assessment of potential MBMs.

\section{A. Technical Measures}

The EEDI is the main technical measure regulated by the revised Annex VI to the MARPOL Convention in 2011. The EEDI provides a specific figure representing a minimum energy efficiency level for certain ship types and size segments, expressed in grams of carbon dioxide per ship's capacity-nautical mile (for example, gross tonne nautical miles). The lower EEDI indicates better energy efficiency of ship design. Regulations 20 and 21 divide it into

October 2011, the current tonnage and number of ships for these three flags totally cover 4.6 percent of the global fleet.

${ }^{73}$ These four guidelines are: Guidelines on the Method of Calculation of the Attained Energy Efficiency Design Index (EEDI) for New Ships, Resolution MEPC.212(63), Doc MEPC 63/23 (2 March 2012), Annex 8 [EEDI Calculation Guidelines]; Guidelines for the Development of A Ship Energy Efficiency Management Plan (SEEMP), Resolution MEPC.213(63), Doc MEPC 63/23 (2 March 2012), Annex 9 [SEEMP Guidelines]; Guidelines on Survey and Certification of the Energy Efficiency Design Index (EEDI), Resolution MEPC.214(63), Doc MEPC 63/23/Add.1 (2 March 2012), Annex 10 [EEDI Survey and Certification Guidelines]; Guidelines for Calculation of Reference Lines for Use with the Energy Efficiency Design Index (EEDI), Resolution MEPC.215(63), Doc MEPC 63/23/Add.1 (2 March 2012), Annex 11 [EEDI Reference Lines Guidelines]. 
attained EEDI and required EEDI ${ }^{74}$ and both of them are calculated by a formula based on the technical design parameters for a given ship. ${ }^{75}$ Based on the formula, the attained EEDI should be less than or equal to the required EEDI. ${ }^{76}$ As a 'non-prescriptive' and 'performance-based' mechanism, the EEDI only requires a minimum energy-efficiency level. ${ }^{77}$ Provided the EEDI requirement is achieved, ship designers and shipbuilders are free to choose the most cost-efficient solutions for the ship to meet the regulations. The EEDI could provide a strong incentive for the shipping industry to improve ship fuel consumption with updated technical developments. Meanwhile, the EEDI is basically a 'hard rule' rather than a commercial incentive scheme. Based on the mandatory EEDI requirements, substandard ships might be detained, fined by port states, or even forbidden to trade, although the way to achieve the emissions reduction is left to the shipping industry. ${ }^{78}$

Aside from the EEDI waiver clause under Regulation 19 of Annex VI, the EEDI does not apply to all ship types or to all types of propulsion systems. Regulation 21 (required EEDI) only lists seven types of ships, namely bulk carriers, gas carriers, tankers, container ships, general cargo ships, refrigerated cargo ships, and combination carriers. ${ }^{79}$ Ships with diesel-electric propulsion, turbine propulsion, and hybrid propulsion are currently excluded from the EEDI requirement. ${ }^{80}$ The exemptions for these types of ships can be mainly attributed to the technical difficulty of incorporating them into the current EEDI formulae due to the complexity of the shipping emissions. Nevertheless, as the first step in reducing the majority of shipping emissions sources, the current EEDI coverage has embraced 70 percent of emissions from new ships. ${ }^{81}$ The regulated seven types of ships are essentially those designed to transport cargos, representing 'the largest and most energy intensive segments of

${ }^{74}$ Attained EEDI refers to the EEDI value achieved by an individual ship in accordance with Regulation 20 of chapter 4, MARPOL Convention, supra note 13, Annex VI; while required EEDI is the maximum value of attained EEDI that is allowed by Regulation 21 of chapter 4 for the specific ship type and size. MARPOL Convention, supra note 13, Annex VI (2011), Regulation 2.36-37.

75 The formula of required EEDI is indicated by Regulation 21 of MARPOL Annex VI, while the formula of attained EEDI is provided by its guidelines. Guidelines on the Method of Calculation of the Attained Energy Efficiency Design Index (EEDI) for New Ships, Resolution MEPC.212(63), Doc MEPC 63/23 (2 March 2012), Annex 8, Article 2.

${ }^{76}$ MARPOL Convention, supra note 13, Annex VI (2011), Regulation 21.1.3.

${ }^{77} \mathrm{IMO}$, supra note 42 at 12.

${ }^{78}$ Wang Erde, 'Consensus Achieved by Reduction Negotiations and China Is to Start Its Reduction in 2019,' Twenty-First Century Business Herald (Beijing), 26 July 2011. [in Chinese].

${ }^{79}$ MARPOL Convention, supra note 13, Annex VI (2011), Regulation 21, Table 1, 2.

${ }^{80}$ Ibid, Regulation 19.3.

${ }^{81}$ IMO, supra note 42, Annex 1, 32. 
the world merchant fleet. ${ }^{82}$ The MEPC is currently working on the development of EEDI frameworks for ships not covered by the current EEDI, such as roll-on-roll-off (ro-ro) cargo ships, ro-ro passenger ships, passenger ships, as well as ships with non-conventional propulsion systems. ${ }^{83}$ This step-by-step approach was utilized by the IMO to relieve strong opposition from developing countries and expedite the regulation progress within the MEPC. However, the amendment was not reached by consensus within the MEPC, which indicates a challenge on future implementation. ${ }^{84}$ As a global mandatory instrument, the amended Annex VI requests port states to verify if there is a valid International Energy Efficiency Certificate on ships calling at their ports so as to monitor the compliance of ships. ${ }^{85}$ Nevertheless, some flag states may not join the instrument, and the ships flying their flags may seek suitable routes to avoid the regulation. To facilitate the enforcement of EEDI requirements, the amendment and subsequent guidelines have provided a phased approach, and an IMO commissioned report offers technological options.

First, Regulation 21 provides four phases for the implementation of the EEDI. Phase 0 (1 January 2013-31 December 2014) provides a two-year grace period for all ships regardless of their flags to be exempt from EEDI requirements. This regulation gives the shipping industry lead time to do necessary preparations such as technology research and development and staff training. This measure was initially proposed by China as a five-year Phase 0 and was supported by other developing countries. ${ }^{86}$ Thus, it is actually a compromise achieved between developed countries and developing countries. In Phase 1 (1 January 2015-31 December 2019), a carbon dioxide reduction level of 10 percent is mandated, and this percentage will become higher every five years to be in line with updated technological developments in efficiency and reduction measures. In Phase 3 (1 January 2025 onwards), a 30 percent reduction is set for most ship types calculated from a reference line for ships built

${ }^{82}$ Ibid at 12 .

${ }^{83}$ Ships with non-conventional propulsion systems refer to ships with diesel-electric propulsion, turbine propulsion, and hybrid propulsion.

${ }^{84}$ Md Saiful Karim, IMO Mndatory Eergy Efficiency Measures for International Shipping: The First Mantory Global Greenhouse Gas Reduction Instrument for an International Industry 7(1) Macquarie J Int'l \& Comp Envt'l L 111, 113 (2011).

${ }^{85}$ MARPOL Convention, supra note 13, Annex VI (2011), Regulation 10.5.

${ }^{86}$ Report of the Outcomes of the Intersessional Meeting of the Working Group on Energy Efficiency Measures for Ships, MEPC $61^{\text {st }}$ Session, Agenda Item 5, Doc MEPC 61/5/3 (7 July 2010) at para 2.19.2. In Doc EE-WG 1/2, China argued that the reduction rate $X$ should not be implemented immediately once the mandatory EEDI takes effect and that is $\mathrm{X}=0$ for the first phase for five years. 
between 2000 and $2010 .{ }^{87}$ This schedule for implementation follows a step-by-step approach and provides differentiated requirements for different ship sizes. Generally, the EEDI requirements on ship size below certain capacities are lower. This arrangement meets the special demand by various states for trade considerations, physical port limitations, and cargo logistic issues since not all states need large-size ships. Although, according to the economics theory of 'economies of scale,' at a given speed, the larger the ship the lower the fuel consumption per unit of cargo. ${ }^{88}$

Second, to meet the EEDI requirements for new ships, the selection of technologies is vital for ship designers and shipbuilders. An assessment report commissioned by the IMO provides fifteen types of technologies for reducing future ship's EEDI as shown in Table $1 .^{89}$ These technologies can be classified into five groups, namely:

- $\quad$ ship capacity enhancement;

- $\quad$ hull and propeller;

- $\quad$ engines, waste heat recovery, and propulsion system;

- $\quad$ alternative fuels; and

- $\quad$ alternative sources of energy. ${ }^{90}$

Table 1. Technologies for EEDI Reduction

\begin{tabular}{|l|l|l|}
\hline No. & EEDI Reduction Measures & Remark \\
\hline 1 & Optimized hull dimensions and form & $\begin{array}{l}\text { Ship design for efficiency via choice of main dimensions } \\
\text { (port and canal restrictions) and hull forms }\end{array}$ \\
\hline 2 & Lightweight construction & New lightweight ship construction material \\
\hline 3 & Hull coating & Use of advanced hull coatings/paints \\
\hline 4 & Hull air lubrication system & $\begin{array}{l}\text { Air cavity via injection of air under/around the hull to reduce } \\
\text { wet surface and thereby ship resistance }\end{array}$ \\
\hline 5 & Optimization of propeller-hull & Propeller-hull-rudder design optimization plus relevant \\
\hline
\end{tabular}

${ }^{87}$ A reference line refers to 'a curve representing an average index value fitted on a set of individual index values for a defined group of ships,' so it represents the average efficiency for ships. The reference line was also called baseline but was later abandoned by the MEPC as the reference line can better reflect its purpose and function. EEDI Survey and Certification Guidelines, supra note 73, Article 4; IMO, supra note 42 at 12.

${ }^{88}$ IMO, supra note 42 at 34.

${ }^{89}$ Ibid at 14-15. EEDI Calculation Guidelines, supra note 73.

${ }^{90}$ Ibid. 


\begin{tabular}{|c|c|c|}
\hline & interface and flow devices & changes to ship's aft body \\
\hline 6 & Contra-rotating propeller & Two propellers in series; rotating at different direction \\
\hline 7 & Engine efficiency improvement & $\begin{array}{l}\text { De-rating, long-stroke, electronic injection, variable } \\
\text { geometry turbocharging, and so on }\end{array}$ \\
\hline 8 & Waster heat recovery & $\begin{array}{l}\text { Main and auxiliary engines' exhaust gas waste heat recovery } \\
\text { and conversion to electric power }\end{array}$ \\
\hline 9 & Gas fuelled & Natural gas fuel and dual fuel engines \\
\hline 10 & $\begin{array}{l}\text { Hybrid electric power and } \\
\text { propulsion concepts }\end{array}$ & $\begin{array}{l}\text { For some ships, the use of electric or hybrid would be more } \\
\text { efficient }\end{array}$ \\
\hline 11 & $\begin{array}{l}\text { Reducing on-board power demand } \\
\text { (auxiliary system and hotel loads) }\end{array}$ & $\begin{array}{l}\text { Maximum heat recovery and minimizing required electrical } \\
\text { loads flexible power solutions and power management }\end{array}$ \\
\hline 12 & $\begin{array}{l}\text { Variable speed drive for pumps, } \\
\text { fans, and so on }\end{array}$ & $\begin{array}{l}\text { Use of variable speed electric motors for control of rotating } \\
\text { flow machinery leads to significant reduction in their energy } \\
\text { use }\end{array}$ \\
\hline 13 & $\begin{array}{l}\text { Wind power (sail, wind engine, and } \\
\text { so on) }\end{array}$ & $\begin{array}{l}\text { Sails, flettner rotor, kites, and so on, which are considered to } \\
\text { be emerging technologies }\end{array}$ \\
\hline 14 & Solar power & Solar photovoltaic cells \\
\hline 15 & Design speed reduction (new builds) & $\begin{array}{l}\text { Reducing design speed via choice of lower power or derated } \\
\text { engines }\end{array}$ \\
\hline
\end{tabular}

Source: Zabi Bazari and Tore Longva, Assessment of IMO Mandated Energy Efficiency Measures for International Shipping, Doc MEPC 63/INF.2 (31 October 2011), Annex at 14-15.

Compared with the seven types of technologies available for new ships as indicated in the first IMO GHG study, there are currently more choices available for the shipping industry. ${ }^{91}$ It is projected that during Phases 0 and 1 (1 January 2013-31 December 2019), hull, propeller, and main engine optimization will contribute more to EEDI compliance, while during Phases 2 and 3 (1 January 2020 onwards), new technologies and design speed reduction will be utilized more to meet the EEDI requirements. ${ }^{92}$ The order of these technologies does not imply any prioritization. However, it is of 'critical importance' to ensure safe navigation under adverse conditions, while energy efficiency of international shipping is promoted. ${ }^{93}$ Based on this understanding, the need for a minimum speed is

\footnotetext{
${ }^{91}$ Skjølsvik et al, supra note 44 at 14.

${ }^{92}$ Bazari and Longva, supra note 70 at 15.

${ }^{93}$ IMO, supra note 42 at 34.
} 
incorporated into the EEDI formula and into Regulation 21.5 of Annex VI, although reducing speed is generally regarded as the easiest way to improve a ship's fuel efficiency. ${ }^{94}$

Third, to ensure the smooth and uniform implementation of the EEDI, Annex VI and the Guidelines on Survey and Certification of the Energy Efficiency Design Index (EEDI Survey and Certification Guidelines) regulate a two-stage survey and verification process. ${ }^{95}$ Based on regulations 5, 6, 7, 8, and 9 of Annex VI and the Guidelines on the Method of Calculation of the Attained Energy Efficiency Design Index (EEDI Calculation Guidelines), the EEDI Survey and Certification Guidelines divide the process into two stages: preliminary verification at the design stage and final verification at sea trial. ${ }^{96}$ At the first stage, a report of pre-verification will be provided by the verifier to the submitter once the verification is complete. At the second stage, a certificate will be issued if a ship has passed the certification. Through this process, verifiers of the EEDI of ships ensure that ships under survey and certification comply with the EEDI requirements. ${ }^{97}$

\section{B. Operational Measures}

The SEEMP is the operational measure regulated by Annex VI of the MARPOL Convention, and it constitutes the other component of the energy efficiency measures besides the EEDI. This plan provides a flexible mechanism for shipowners and ship operators to monitor ship and fleet efficiency performance over time in a cost-effective manner. The main objective of the plan is to minimize shipping GHG emissions by means of reducing fuel consumption, ${ }^{98}$ while the energy efficiency operational indicator (EEOI) is often utilized as a monitoring tool and to establish benchmarks related to the ships' energy efficiency. ${ }^{99}$ Regulation 22 of Annex VI briefly regulates the SEEMP, which provides that '[e]ach ship shall keep on board a ship

\footnotetext{
${ }^{94}$ MARPOL Convention, supra note 13, Annex VI (2011), Regulation 21.1, 21.5.

${ }^{95}$ EEDI Survey and Certification Guidelines, supra note 73.

${ }^{96}$ EEDI Calculation Guidelines, supra note 73.

${ }^{97}$ Verifier means 'an Administration or organization duly authorized by it' or, in other words, flag state or organizations duly authorized by it. EEDI Survey and Certification Guidelines, supra note 73, Article 2.1.

${ }^{98}$ Bazari and Longva, supra note 70, Appendix 4, 12.

${ }^{99}$ The energy efficiency operational indicator (EEOI) can be applied to almost all new and existing ships and is generally used to measure ships energy efficiency at each voyage or over a certain period of time. It enables ship operators to measure the fuel efficiency of a ship in operation and to gauge the effect of any changes in operation. Currently, the EEOI is circulated to encourage shipowners and ship operators to use it on a voluntary basis.
} 
specific Ship Energy Efficiency Management Plan (SEEMP). This may form part of the ship's Safety Management System (SMS). ${ }^{, 00}$

Based on Regulations 19.1 and 22.1 of Annex VI, the SEEMP applies to all existing and new ships of 400 gross tonnage and above on a mandatory basis. As a 'ship specific' plan, the SEEMP adopts a four-step approach to improve a ship's energy efficiency, namely planning, implementation, monitoring, and self-evaluation and improvement. The Guidelines for the Development of a Ship Energy Efficiency Management Plan (SEEMP Guidelines) introduce procedures and measures at each stage and incorporate best practices for the fuelefficient operation of ships. ${ }^{101}$ Moreover, similar to the EEDI Guidelines, the SEEMP Guidelines also highlight the importance of safe navigation. ${ }^{102}$ By introducing specific procedures, measures, and best practices along with the four stages of the plan, the SEEMP urges shipowners and ship operators at each stage to consider new technologies and practices when seeking to optimize the energy-efficiency performance of a ship. Additionally, the guidelines provide a reference for the classification societies and shipping companies to make their own SEEMPs.

To meet these SEEMP requirements, it is important for a ship to adopt specific operational measures for each voyage. Operational measures aiming to reduce the fuel consumption and carbon dioxide emissions can be classified into three categories. ${ }^{103}$ The first category is enhanced technical and operational management. Measures related to enhanced weather routing, hull and propeller cleaning, better main and auxiliary engine maintenance and turning, and efficient operation of larger electrical consumers are in this category. The second category is enhanced logistics and fleet planning. For instance, combining cargoes to achieve a higher utilization rate, optimization of logistic chains, larger cargo batches, adjustments for optimized arrival times and slower steaming, and changed contract formats between charter and shipowner. The third category is port-related measures. Examples include larger port capacity, quicker loading and discharging, flexible design of cargo handling equipment, more efficient port clearance and slot time allocation, and fewer restrictions on ship draft, beam, or length.

${ }^{100}$ MARPOL Convention, supra note 13, Annex VI (2011), Regulation 22.1.

${ }^{101}$ SEEMP Guidelines, supra note 73, Article 5.

102 Ibid, Article 3.7.

${ }^{103}$ The information on this classification comes from the IMO Assessment Report on Energy Efficiency Measures for International Shipping, reprinted in Bazari and Longva, supra note 70, Annex, 15. 
A well-implemented SEEMP might lead to enhanced technical and operational management as illustrated earlier in the first category. ${ }^{104}$ The second and third categories, however, are less influenced by the SEEMP since they involve many stakeholders, which makes their implementation rely heavily on the co-operation of many people and groups.

\section{Assessment of Current Technical and Operational Measures}

As the first ever mandatory and legally binding energy efficiency standards, ${ }^{105}$ the EEDI and the SEEMP are the main technical and operational measures adopted by amendments to Annex VI of the MARPOL Convention in July 2011. The adoption of these measures was a breakthrough in the lengthy deadlock of the political negotiations on shipping GHG emissions within the IMO and also confirmed the leading role of the IMO in regulating the issue. ${ }^{106}$ According to an IMO assessment report, the combined EEDI and SEEMP will lead to significant emission reductions. ${ }^{107}$ This reduction, if valued in terms of annual fuel cost savings, will reach about US $\$ 50$ billion in 2020 and get to US $\$ 200$ billion by $2030 .{ }^{108}$ Meanwhile, the cost of EEDI compliance for an 'average ship' will not be significant, although this cost will be higher in Phase 2 and 3 than in Phase 0 and 1 due to possible investment on design-speed reduction. ${ }^{109}$ Therefore, the overall carbon dioxide reduction resulting from the implementation of current technical and operational measures will be not only 'positive' but also economically sound for the shipping industry.

Both the EEDI and the SEEMP highlight the importance of safe navigation of ships while also improving the energy efficiency of shipping. ${ }^{110}$ The EEDI and SEEMP requirements are linked to other IMO treaties on maritime safety and security, such as the

\footnotetext{
104 Ibid.

${ }^{105}$ IMO, supra note 58.
}

${ }^{106}$ For example, Ban Kin-moon, UN secretary-general said in acknowledgment of the decision of the parties to Annex VI of the MARPOL Convention to adopt mandatory energy efficiency measures during MEPC-62, stated: 'I would like to congratulate you on this significant outcome reached at IMO's MEPC 62. This underscores the fact that IMO is the best positioned to play a leadership role in addressing GHG emissions from international shipping. This is indeed very welcome progress.' IMO, supra note 42 at 22 , para 99.

${ }^{107}$ Bazari and Longva, supra note 70 at 8 , executive summary.

108 Ibid.

${ }^{109}$ Ibid.

${ }^{110}$ See, eg, MARPOL Convention, supra note 13, Annex VI (2011), Regulation 21.5, 22.1; SEEMP Guidelines, supra note 73, Article 3.7. 
1972 Convention on the International Regulations for Preventing Collisions at Sea. ${ }^{111}$ To meet the safety requirements, a technological threshold is to be achieved by shipowners and ship operators. Additionally, both the EEDI and the SEEMP provide a strong incentive for the shipping industry to choose and update cost-efficient technologies to meet the criteria set under the EEDI and the SEEMP. The shipping industry can freely choose the technologies provided that they meet the requirements. This 'freedom from prescription' approach is vital for the success of this mechanism on the ground that it was strongly supported by the global shipping industry before it was adopted by the IMO. ${ }^{112}$ Since it is almost impossible to implement these IMO instruments, including the technical and operational measures, without compliance by the shipping industry, their active participation is essential.

Another example of these efforts is the negotiation on the possible approval of the SEEMP by flag state administrations. During the sixtieth and sixty-first MEPC meetings, many state delegations supported the proposal that the contents of the SEEMP should be examined by the administration or organization recognized by the administration as a rule, ${ }^{113}$ while other state delegations and many industry representatives stressed that the SEEMP should not be approved by the administration but may be audited as a part of the ship's safety management systems. ${ }^{114}$ Eventually, it was agreed that approval of the SEEMP by flag state administrations would not be required. This was to a significant extent achieved by many international shipping associations and could be deemed a victory of the shipping industry against the flag states. Where the SEEMP of a ship needs to be approved by its flag state, it will be often less efficient and more costly for the shipowners, whereas it may be beneficial for flag states to better manage their ships. Moreover, in view of the current 'flag of

${ }^{111}$ Convention on the International Regulations for Preventing Collisions at Sea, UKTS 77 (1972).

${ }^{112}$ See, eg, at the fifty-seventh MEPC meeting, the International Chamber of Shipping (ICS) proposed five principles for guiding the amendment of MARPOL Annex VI, and one of them is that the ship operators should have the freedom to choose their compliance mechanism so as to protect the shipping industry form monopolistic situations. It treated the 'freedom from prescription' as the most effective means for stimulating future innovation. Revision of MARPOL Annex VI, submitted by the ICS, MEPC $57^{\text {th }}$ Session, Agenda Item 4, Doc MEPC 57/4/28 (13 February 2008) at para 5.3.

${ }^{113}$ Generally, the 'Administration' refers to a flag state and the 'organisation recognised by the Administration' refers to the classification society in that flag state.

${ }^{114}$ Report of the Outcomes of the Intersessional Meeting of the Working Group on Energy Efficiency Measures for Ships, MEPC $61^{\text {st }}$ Session, Agenda Item 5, Doc MEPC 61/5/3 (7 July 2010) at 10, para 2.24. 
convenience' problem, ${ }^{115}$ to rely the examination of a ship's SEEMP on the audit of a ship's safety management system rather than on the approval of a flag state's administration is also beneficial for the reduction of GHG emissions from international shipping. This is because many open registry states often do not have enough motive and expertise to organize this examination of the SEEMP.

Despite the benefits of these technical and operational measures, some deficiencies remain and impose challenges for the future implementation of these measures. As far as the EEDI is concerned, it only applies to certain types of new ships (only covers 70 percent of emissions from new ships), and existing ships are not, and technically will not be, covered by the EEDI. This deficiency, if combined with the very lenient timetable as introduced in the regulation and the projected growth in international trade, would reduce to a significant extent the effectiveness of the EEDI. Additionally, future regulation for the remaining types of new ships may adopt different energy efficiency standards, which would increase the difficulty of effective enforcement. With respect to the MARPOL Convention, implementation mainly relies on flag states and port states. The IMO sets energy efficiency standards itself through Annex VI of the MARPOL Convention. However, the authority it gives to port states is limited. The added paragraph 5 of Regulation 10 of Annex VI provides that '[i]n relation to chapter 4, any port State inspection shall be limited to verifying, when appropriate, that there is a valid International Energy Efficiency Certificate on board, in accordance with article 5 of the Convention., 116

Through this regulation, the IMO attempts to exclude unilateral actions by port states in dealing with shipping GHG emissions. Nevertheless, it will be beneficial for the global reduction of GHG emissions from ships if some states take further steps in this regard. It is also believed that potential regulatory competition between different institutions will provide a significant motivation for the IMO to facilitate its work. ${ }^{117}$ An example of unilateral action is the inclusion of the emissions from the international aviation industry into the emission trading scheme of the EU. Although this initiative has been suspended due to opposition from

${ }^{115}$ A 'flag of convenience' refers to 'the flag of any country allowing the registration of foreign-owned and foreign-controlled vessels under conditions which for whatever the reasons, are convenient and opportune for the persons who are registering the vessels.' BA Boczek, Flags of Convenience: An International Legal Study, at 117 (1962).

${ }^{116}$ MARPOL Convention, supra note 13, Annex VI (2011), Regulation 10.5.

117 Oberthür, supra note 10 at 202. 
various developed and developing countries, ${ }^{118}$ it has motivated to some extent the efforts of the ICAO in accelerating its work under the Kyoto Protocol. ${ }^{119}$

The SEEMP is introduced as representing a reduction measure for existing and new ships. Basically, it is a management scheme that entails no reduction requirement at all. To a significant extent, the lack of reduction target setting and monitoring reduces the effectiveness of the SEEMP. ${ }^{120}$ This deficiency needs to be rectified by means of other incentives to be provided. ${ }^{121}$ It is also recommended by an IMO assessment report that EEOI should be encouraged or mandated as a performance indicator for the SEEMP rather than remain as a voluntary provision. ${ }^{122}$

Another challenge comes from the future enforcement of these measures by developing countries that opposed the adoption of the measures. Regulation 23 of Annex VI to the MARPOL Convention underscores the promotion of technical co-operation and transfer of technology, aiming to strengthen the capacity building of developing countries. This mechanism, if well designed, could be regarded as a kind of differentiated treatment. Since common responsibility and differentiated responsibility are two core elements of the CBDR principle, and common responsibility has been incorporated in this context via the NMFT principle, ${ }^{123}$ the proper design and implementation of the technical co-operation and transfer of technology elements of this mechanism might constitute the application of the CBDR principle. However, Regulation 23 lacks 'concrete obligations' on any state ${ }^{124}$ and stipulates that this technical co-operation is subject to national laws, regulations, and

${ }^{118}$ The European Union (EU) has included the emissions from the international aviation sector into its emissions trading scheme since 1 January 2012, which charges carbon tax to all airlines that fly in and out of the EU. This policy suspended in December 2012 due to strong opposition from many countries including the United States, Russia, China, and India. See Elena Ares, EU ETS and Aviation (23 May 2012) $<$ http://www.parliament.uk/briefing-papers/SN05533.pdf>.

${ }^{119}$ Kyoto Protocol, supra note 5, Article 2(2).

${ }^{120}$ Bazari and Longva, supra note 70 at 7 , executive summary.

${ }^{121}$ Ibid, Annex 15. The report lists some of the drivers for more effective use of the SEEMP, including high fuel and carbon prices, more vigorous awareness building, and cultural change on board ships, more collaboration between industry stakeholders and a solution to issue of split incentives, and effective monitoring of SEEMP

122 Ibid at 7. implementation via rigorous audits and reviews.

${ }^{123}$ MARPOL Convention, supra note 13, Article 5(4).

${ }^{124}$ James Harrison, Recent Developments and Continuing Challenges in the Regulation of Greenhouse Gas Emissions from International Shipping, University of Edinburgh, Research Paper Series, at 16 (2012), <http://ssrn.com/abstract=2037038> . 
policies. ${ }^{125}$ It is expected that the transfer of technology from developed countries to developing countries will not be straightforward due to various domestic regulations on intellectual property protection in developed countries. ${ }^{126}$ In developed countries, most energy-efficient technologies are owned by private shipping companies. Therefore, how to achieve the successful transfer of technologies in a cost-effective manner remains a difficult question.

Figure 1 is one scenario devised by a recent IMO Assessment Study on Energy Efficiency Measures. ${ }^{127}$ The figure shows that based on the 2010 carbon dioxide emissions level, it is almost impossible to achieve absolute emission reduction from 2010 to 2050 using the EEDI and SEEMP alone. This is because new emissions produced by increased world trade outweigh the emissions reductions achieved by these two measures. For all scenarios, this conclusion is the same. Therefore, in addition to technical and operational measures already adopted by Annex VI of the MARPOL Convention, the international community has turned to MBMs to explore their utility in the possible reduction of GHG emissions from international shipping.

World fleet - Scenario: A1B-4 Fuel: High, SEEMP uptake: High , Waiver: 5\%

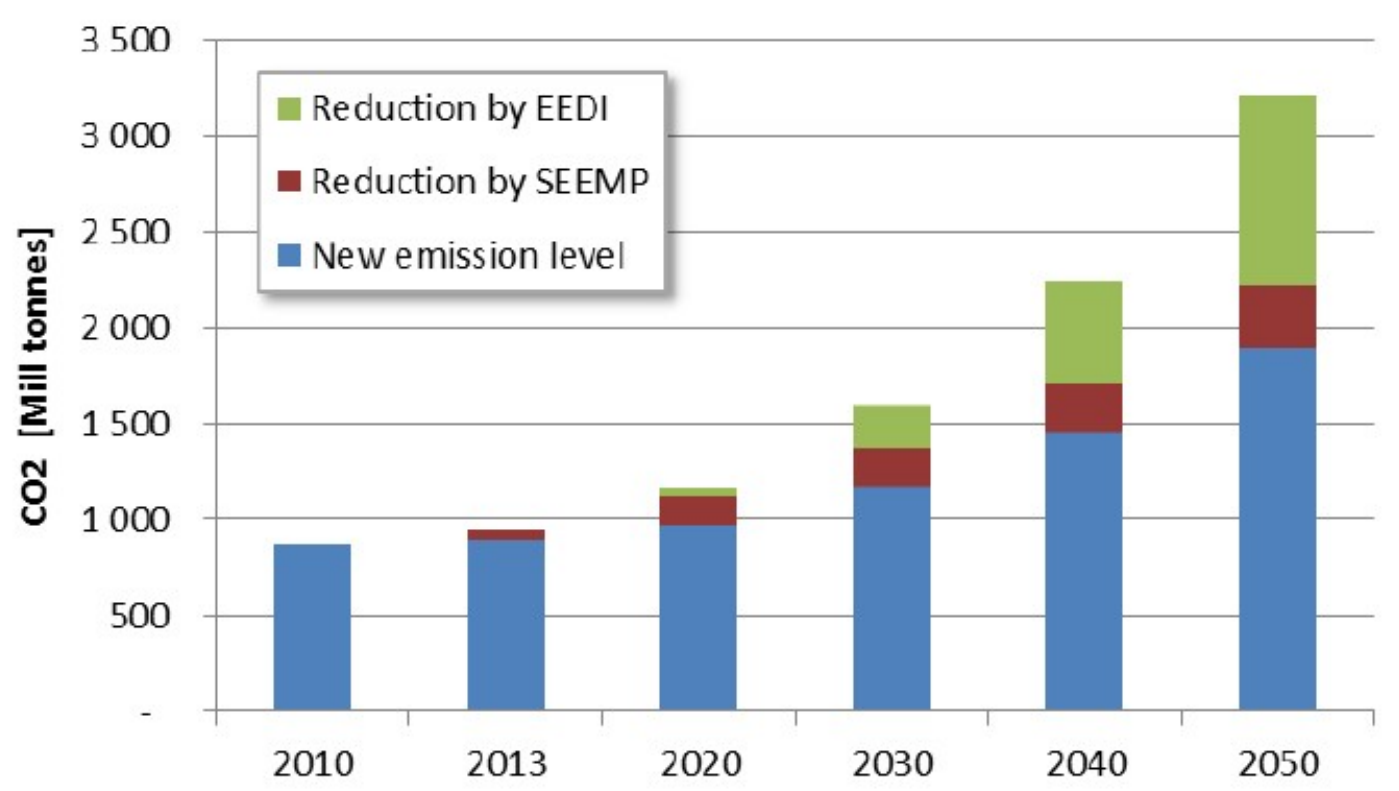

Figure 1. Annual Emission Reduction by 2050 and New Emissions Levels (scenario A1B-4)

\footnotetext{
${ }^{125}$ MARPOL Convention, supra note 13, Annex VI (2011), Regulation 23.2.

${ }^{126}$ Harrison, supra note 124 at 17.

${ }^{127}$ Bazari and Longva, supra note 70 at 8 , executive summary.
} 
Source: Zabi Bazari and Tore Longva, Assessment of IMO Mandated Energy Efficiency Measures for International Shipping, Doc MEPC 63/INF.2 (31 October 2011), Annex at 5.

\section{MBMs}

MBMs, which are also referred to as market-based instruments or market-based mechanisms, are generally regarded as an important supplement to the technical and operational measures already in place in reducing GHG emissions from international shipping. In accordance with the polluter pays principle, MBMs aim to provide the polluters (shipowners and ship operators) with an economic incentive to reduce their GHG emissions. ${ }^{128}$ As a comparatively new concept in the shipping context, MBMs have been controversial since they were formally put forward in the 2000 IMO GHG study. The IMO has endeavoured to promote the awareness of MBMs by relevant stakeholders of the GHG issue. As a follow up to the 2000 GHG study commissioned by the IMO, the Scientific Study on International Shipping and Market-Based Instruments (Scientific Study) was published in December 2009. ${ }^{129}$ In August 2010, another IMO-commissioned report undertaken by the Expert Group on Feasibility Study and Impact Assessment of Possible Market-based Measures (Expert Group) was released, the Full Report of the Work Undertaken by the Expert Group on Feasibility Study and Impact Assessment of Possible Market-based Measures (Feasibility Study and Impact Assessment Report). ${ }^{130}$ Currently, a report commissioned by the IMO on possible impacts on consumers and industries in developing countries is under way and is expected to be finalized at the sixty-sixth MEPC meeting in 2014. Through this work, most countries have come to accept MBMs, and seven main types of proposals have been submitted to the IMO for future discussion, although some countries still oppose the adoption of any MBM. ${ }^{131}$ This following sections explore the necessity for adopting MBMs and then provide a feasibility and impact assessment of current MBM options.

${ }^{128}$ Psaraftis, supra note 15 at 213.

${ }^{129}$ Scientific Study on International Shipping and Market-based Instruments, MEPC $60^{\text {th }}$ Session, Agenda Item 4, Doc MEPC 60/INF.21 (15 January 2010).

${ }^{130}$ Full Report of the Work Undertaken by the Expert Group on Feasibility Study and Impact Assessment of Possible Market-based Measures, MEPC $61^{\text {st }}$ Session, Agenda Item 5, Doc MEPC 61/INF.2 (13 August 2010).

${ }^{131}$ See, eg, Uncertainties and Problems in Market-based Measures, submitted by China and India, MEPC $61^{\text {st }}$ Session, Agenda Item 5, Doc MEPC 61/5/24 (5 August 2010); Market-based Measures: Inequitable Burden on Developing Countries, submitted by India, MEPC $61^{\text {st }}$ Session, Agenda Item 5, Doc MEPC 61/5/19 (2 August 2010). 


\section{A. The Necessity of MBMs in Reducing Shipping GHG Emissions}

In economics theory, the emergence of MBMs has been interpreted as an approach to overcome the problem of environmental externalities. ${ }^{132}$ MBMs are one of the main types of environmental policies, ${ }^{133}$ and they have been employed by many countries to regulate adverse environmental impacts resulting from anthropogenic activities. As defined by the Organization for Economic Cooperation and Development (OECD),

[MBMs] seek to address the market failure of 'environmental externalities' either by incorporating the external cost of production or consumption activities through taxes or charges on processes or products, or by creating property rights and facilitating the establishment of a proxy market for the use of environmental services. ${ }^{134}$

MBMs can be classified into three groups, namely environmental fees (contribution), tradable permit (allowance) schemes, and liability rules. ${ }^{135}$ Nevertheless, there is no 'one-size-fits-all' MBM. In practice, different MBMs provide solutions for different problems, and some issues might need a mix of two or three types of MBMs.

In the context of GHG emissions from shipping, MBMs can be designed to internalize the external cost of GHG emissions from international shipping by means of a GHG fund or different emission trading schemes. However, the first step is to decide whether MBMs are needed for the reduction of GHG emissions from international shipping. It is a difficult question. Many developing countries, in particular China, India, and Brazil, oppose the adoption of any MBMs. Their argument has mainly been underpinned by three reasons. One is the uncertainty associated with MBMs, including those of the carbon market, the calculation of the emissions from international shipping, and the effect of a carbon tax on ships on the export industry as well as on the future development of the shipping industry and

${ }^{132}$ Environmental externalities 'refer to the economic concept of uncompensated environmental effects of production and consumption that affect consumer utility and enterprise cost outside the market mechanism.' OECD, Environmental Externalities $<$ http://stats.oecd.org/glossary/detail.asp?ID=824>.

${ }^{133}$ Environmental policies are often classified as command and control, market-based, education, provision of information, and voluntary measures. Thomas Dietz and Paul C Stern, Exploring New Tools for Environmental Protection, in Thomas Dietz and Paul C Stern (eds), New Tools for Environmental Protection: Education, Information, and Voluntary Measures, at 4 (2002),

${ }^{134}$ OECD, Market-based Instruments, <http://stats.oecd.org/glossary/detail.asp?ID=7214>.

135 Scientific Study on International Shipping and Market-based Instruments, MEPC $60^{\text {th }}$ Session, Agenda Item 4, Doc MEPC 60/INF.21 (15 January 2010) at 14, Annex. 
world trade. ${ }^{136}$ Another reason lies in the fundamental inadequacies both in theory and in principle. Developing countries argue that the implementation of current MBM proposals requires several prerequisites so as to avert the distortion of competition, such as the same or similar level of economic and technological development realized among all participating countries, some convergence of political power, and the deployment of a common central institution. $^{137}$

They also assert that the NMFT principle incorporated in the majority of current MBM proposals ignores historical responsibility and is a disadvantage for developing countries. ${ }^{138}$ Moreover, some of the proposed MBMs are regarded by some developing countries as being likely to violate WTO rules. ${ }^{139}$ For instance, the MBM on Port State Levy proposed by Jamaica envisages levying a globally uniform emissions charge on all vessels calling at their respective ports, based on the amount of pollution produced by the vessel during the voyage (see Table 2). This proposal measures the amount of pollution by the amount of fuels consumed, which due to different ship types and operational methods may not be accurate. In this case, it actually leads to differentiated treatment of different ships, which might possibly contravene the general most-favoured-nation treatment as incorporated in Article I of the General Agreement on Tariffs and Trade. ${ }^{140}$

In contrast to developing countries, most developed countries and NGOs are in favour of certain types of MBMs and have actually submitted their proposals to the IMO, although they disagree with each other on what type of MBM is best. The reason is simple-the current EEDI and SEEMP are not sufficient for effective reduction of GHG emissions from international shipping due to the projected growth of international seaborne trade, and, thus, specific types of MBMs are needed to supplement the energy-efficiency measures.

While intensive discussions on MBMs have been held within the IMO, it is predicted that a form of MBM will be adopted in the near future by the IMO or other international institutions to reduce emissions from ships. First, as discussed earlier, to achieve absolute emission reduction using EEDI and SEEMP alone is not possible in practice, which has been

\footnotetext{
${ }^{136}$ Uncertainties and Problems in Market-based Measures, submitted by China and India, MEPC $61^{\text {st }}$ Session, Agenda Item 5, Doc MEPC 61/5/24 (5 August 2010) at 2. ${ }^{137}$ Ibid at 3.

${ }^{138}$ Ibid; Market-based Measures: Inequitable Burden on Developing Countries, submitted by India, MEPC $61^{\text {st }}$ Session, Agenda Item 5, Doc MEPC 61/5/19 (2 August 2010) at 3.

${ }^{139}$ See, eg, Possible Incompatibility between the WTO Rules and Market-based Measures for International Shipping, submitted by India and Saudi Arabia, MEPC $64^{\text {th }}$ Session, Agenda Item 5, Doc MEPC 64/5/3 (29 June 2012).

${ }^{140}$ Ibid at para 25. General Agreement on Tariffs and Trade, 55 UNTS 194.
} 
proven by a number of scenario modellings, revealed in many assessment reports. ${ }^{141}$ Moreover, the EEDI and SEEMP regulations only entered into force on 1 January 2013, so in practice their compliance by various states and their emissions reduction potential cannot be identified in the short term. The shipping industry has recognized the deficiencies of these measures and relevant work on their improvement has been conducted within the IMO. However, given the intricacies of ship types and shipping features, a technical breakthrough is hardly likely to be achieved soon. Currently, global emissions are 'considerably higher' than the level consistent with the 2 degree Celcius target in 2020, and this trend continues. ${ }^{142}$ Under the circumstances, it is necessary for the international shipping industry to explore and discuss the possibility of adopting MBMs for more GHG reduction rather than waiting for the effects of applying energy-efficiency measures to be practically identified.

Second, it is technically possible to incorporate the CBDR principle into a future MBM, and proposals applying the principle have been submitted to the IMO by different countries and NGOs. ${ }^{143}$ As shown in the comments by some developing countries, the core debate within the MEPC lies in the ignorance of the CBDR principle reflected in many MBM proposals. Once this problem is resolved, it may be possible to adopt MBMs that are accepted by most countries. It seems that any MBM proposal that ignores the CBDR principle would be hardly feasible on the ground that the CBDR principle in the shipping context has been supported by 'the majority of delegations' within the MEPC. ${ }^{144}$ In recent years, some international shipping organizations, as well as the shipowners' associations in states listed in

${ }^{141}$ Bazari and Longva, supra note 70 at 8 , executive summary.

${ }^{142}$ United Nations Environment Programme (UNEP), The Emissions Gap Report 2012: A UNEP Synthesis Report (November 2012), $<$ http://www.unep.org/pdf/2012gapreport.pdf> at 1, executive summary.

${ }^{143}$ For example, the WWF suggested that a MBM that is both global and differentiated was possible to develop incorporating both the CBDR and the NMFT principles simultaneously, and it also put forward specific revenue allocation scheme for different countries. Benefits and Possible Adverse Impacts of Market-based Instruments, submitted by WWF, MEPC $58^{\text {th }}$ Session, Agenda Item 4, Doc MEPC 58/4/39 (15 August 2008). This approach was also adopted by the Scientific Study on International Shipping and Market-based Instruments, a study led by the University of Cambridge in partnership with Cambridge Econometrics, MARINTEK, Manchester Metropolitan University, and Deutsches Zentrum für Luft-und Raumfahrt e.V. Scientific Study on International Shipping and Market-based Instruments, MEPC $60^{\text {th }}$ Session, Agenda Item 4, Doc MEPC 60/INF.21 (15 January 2010).

${ }^{144}$ Report of the Marine Environment Protection Committee on its $58^{\text {th }}$ Session, IMO Doc MEPC 58/23 (16 October 2008) at 38, para 4.45. 
Annex I to the UNFCCC, also came to accept the incorporation of the CBDR principle into a proposed MBM. $^{145}$

The possible adoption of MBMs could reduce shipping GHG emissions in two respects: in-sector reduction and out-of-sector reduction. ${ }^{146}$ In the first case, a MBM may provide an economic incentive (for example, a charge on fuel, a refund to 'good performance ships') for the shipping industry to reduce its fuel consumption. The industry might invest in more fuel efficient ships or technologies or operate ships in a more energy-efficient manner. In the second case, the money collected from a MBM could be utilized to reduce GHG emissions outside the marine sector. In this way, growing shipping emissions could be offset by emission reduction in other sectors.

\section{B. The Feasibility and Impact Assessment of MBM Options}

In order to adopt a MBM for the reduction of GHG emissions from international shipping, it is important to know what choices exist and whether they will have adverse impacts on the shipping industry and different countries, in particular, developing countries. Based on these analyses, the selection and adoption of a suitable MBM is possible. Currently, there are seven types of MBM proposals being discussed and debated within the IMO. A brief introduction of these proposals is illustrated in Table 2. To simplify future assessments and facilitate the decision-making process of the MEPC, intensive debate on the grouping of these proposals was held at the third GHG-WG meeting. It was concluded that MBM proposals should be grouped into two categories, the first one focused on in-sector reduction and the second one

\footnotetext{
${ }^{145}$ See, eg, at the fifty-ninth MEPC meeting, Cruise Lines International Association (CLIA) proposed three principles on tackling GHG emissions from ships, namely the NMFT principle, the principle of high quality, multiple benefit carbon mitigation investment, and the CBDR principle. It further explained that a framework established by the IMO on combating climate change should respect both the NMFT principle and the CBDR principle. Consideration of Adoption of Three Principles for Market-based Instruments, submitted by CLIA, MEPC $59^{\text {th }}$ Session, Agenda Item 4, Doc MEPC 59/4/32 (8 May 2009) at para 1. Another example is from Australian Shipowners Association (ASA). In a proposal drafted by the ASA and some of other shipowners association, the ASA supported a 'cap-and-trade' emission-trading scheme for shipping and recognized that the CBDR principle 'may also need to be reflected' in this scheme. ASA et al, A Global Cap-and-Trade System to Reduce Carbon Emissions from International Shipping, at 3 (2009), <http://www.asa.com.au/wpcontent/uploads/Joint-Industry-ETS-Discussion-PapervFINAL1.pdf >.

${ }^{146}$ IMO, Market-based Measures, $<$ http://www.imo.org/OurWork/Environment/PollutionPrevention/AirPollution/Pages/ Market-Based-Measures.aspx>.
} 
focused on in-sector and out-of-sector reduction, as indicated in Table 2. ${ }^{147}$ This grouping is based on the areas in which the reduction of GHG emissions from ships will mainly take place and has received many comments on their strengths and weaknesses from different delegations. ${ }^{148}$ This section divides these MBM options into three groups. They are environmental fee-related MBM proposals, tradable permit scheme-related MBM proposals, and hybrid MBM proposals.

Table 2. Seven Types of MBM Proposals Submitted to the IMO (as of May 2013)

\begin{tabular}{|c|c|c|c|}
\hline MBM proposals & Proponents & $\begin{array}{l}\text { Working mechanisms / Grouping of } \\
\text { emission reduction }\end{array}$ & Base documents \\
\hline \multirow[b]{2}{*}{ GHG Fund } & $\begin{array}{l}\text { Cyprus, Denmark, } \\
\text { the Marshall } \\
\text { Islands, Nigeria, } \\
\text { and the } \\
\text { International } \\
\text { Parcel Tankers } \\
\text { Association } \\
\text { (IPTA) }\end{array}$ & $\begin{array}{l}\text { Establishes a global reduction target for } \\
\text { international shipping, set by either the } \\
\text { UNFCCC or the IMO. Emissions above the } \\
\text { target line would be offset largely by } \\
\text { purchasing approved emission reduction } \\
\text { credits. The offsetting activities would be } \\
\text { financed by a contribution paid by ships on } \\
\text { every tonne of bunker fuel purchased } \\
\text { (Grouping: In-Sector and Out-of-Sector) }\end{array}$ & $\begin{array}{l}\text { MEPC 59/4/5, } \\
\text { MEPC } \\
\text { 60/4/8, } \\
\text { GHG-WG 3/2/1, } \\
\text { GHG-WG 3/3/4 }\end{array}$ \\
\hline & $\begin{array}{l}\text { Clean Shipping } \\
\text { Coalition (CSC) }\end{array}$ & $\begin{array}{l}\text { Establishes a speed-related GHG or } \\
\text { compensation fund to include regulated slow } \\
\text { steaming in the design and impact assessment } \\
\text { of any MBM proposals. It set average target } \\
\text { speeds for different types and sizes of ships } \\
\text { in order to meet the agreed emissions } \\
\text { reduction target set by the IMO for an MBM. } \\
\text { Additional speed levy or contribution would } \\
\text { be payable for ships having higher average } \\
\text { speeds. Revenues could be used to purchase }\end{array}$ & $\begin{array}{l}\text { MEPC 64/5/8, } \\
\text { MEPC 64/INF.14 }\end{array}$ \\
\hline
\end{tabular}

${ }^{147}$ Report of the Third Intersessional Meeting of the Working Group on Greenhouse Gas Emissions from Ships, note by the Secretariat, MEPC $62^{\text {nd }}$ Session, Agenda Item 5, Doc MEPC 62/5/1 (8 April 2011) at para 3.39.

${ }^{148}$ Ibid at para 3.40-3.46; see also Grouping and Evaluation of Proposed MBMs, submitted by Greece, Intersessional Meeting of the Working Group on GHG Emissions from Ships $3^{\text {rd }}$ Session, Agenda Item 3, Doc GHG-WG 3/3 (24 February 2011); The Evaluation on the Relative Strengths and Weaknesses of the Reduction Mechanisms Employed by the MBM Proposals, submitted by the Republic of Korea, Intersessional Meeting of the Working Group on GHG Emissions from Ships $3{ }^{\text {rd }}$ Session, Agenda Item 3, Doc GHG-WG 3/3/1 (25 February 2011). 


\begin{tabular}{|c|c|c|c|}
\hline & & $\begin{array}{l}\text { offsets. } \\
\text { (Grouping: Focus on In-Sector) }\end{array}$ & \\
\hline $\begin{array}{l}\text { Port State Levy } \\
\text { (PSL) }\end{array}$ & Jamaica & $\begin{array}{l}\text { Levies a uniform emissions charge on all } \\
\text { vessels calling at their respective ports based } \\
\text { on the amount of fuel consumed by the } \\
\text { respective vessel on its voyage to that port. } \\
\text { The CBDR principle could be achieved } \\
\text { through a self-administered fund and/or some } \\
\text { international mechanism (Grouping: 'Focus } \\
\text { on In-Sector' and 'In-Sector \& Out-of- } \\
\text { Sector') }\end{array}$ & $\begin{array}{l}\text { MEPC 60/4/40, } \\
\text { MEPC 64/5/4 }\end{array}$ \\
\hline $\begin{array}{l}\text { Efficiency } \\
\text { Incentive Scheme } \\
\text { (EIS) }\end{array}$ & $\begin{array}{l}\text { Japan and World } \\
\text { Shipping Council } \\
\text { (WSC) }\end{array}$ & $\begin{array}{l}\text { All new ships, except for those that meet pre- } \\
\text { set EEDI thresholds and existing ships, are } \\
\text { required to make payment contributions } \\
\text { based on the amount of the bunker fuel } \\
\text { consumed/purchased and the degree to which } \\
\text { the ship's efficiency falls short of a specific } \\
\text { standard. Funds collected go to an } \\
\text { International GHG Fund for further } \\
\text { allocation (Grouping: Focus on In-Sector) }\end{array}$ & $\begin{array}{l}\text { MEPC 60/4/37, } \\
\text { MEPC 60/4/39, } \\
\text { GHG-WG } 3 / 3 / 2, \\
\text { MEPC 63/5/3, } \\
\text { MEPC 64/5/2, } \\
\text { MEPC 64/INF.15 }\end{array}$ \\
\hline $\begin{array}{l}\text { Ship Efficiency } \\
\text { and Credit } \\
\text { Trading (SECT) }\end{array}$ & United Sates & $\begin{array}{l}\text { Subjects all ships to mandatory energy- } \\
\text { efficiency standards. As one means of } \\
\text { complying with the standard, an efficiency } \\
\text { credit trading program would be established. } \\
\text { These standards would become more } \\
\text { stringent over time (Grouping: Focus on In- } \\
\text { Sector) }\end{array}$ & $\begin{array}{l}\text { MEPC 60/4/12, } \\
\text { MEPC 61/5/16, } \\
\text { MEPC 61/IMF.24 }\end{array}$ \\
\hline Global Emissions & $\begin{array}{l}\text { Norway } \\
\text { (later added as co- } \\
\text { sponsor, Germany) }\end{array}$ & $\begin{array}{l}\text { Sets a sector-wide cap on net emissions from } \\
\text { international shipping. A number of } \\
\text { allowances (ship emission units) } \\
\text { corresponding to the cap would be released } \\
\text { into the market each year via a global } \\
\text { auctioning process. The units could then be }\end{array}$ & $\begin{array}{l}\text { МЕPC 60/4/22; } \\
\text { MEPC 60/4/26; } \\
\text { MEPC 60/4/41; }\end{array}$ \\
\hline
\end{tabular}




\begin{tabular}{|c|c|c|c|}
\hline \multirow{4}{*}{$\begin{array}{l}\text { Trading System } \\
\text { (ETS) for } \\
\text { international } \\
\text { shipping }\end{array}$} & & traded. & \multirow{3}{*}{$\begin{array}{l}\text { MEPC 60/4/54; } \\
\text { GHG-WG 3/3/5; } \\
\text { GHG-WG 3/3/6; } \\
\text { GHG-WG 3/3/8 }\end{array}$} \\
\hline & United Kingdom & $\begin{array}{l}\text { Differs from the Norwegian ETS proposal in } \\
\text { two aspects: the method of allocating } \\
\text { emissions allowances (national instead of } \\
\text { global auctioning) and the approach for } \\
\text { setting the emissions cap (set with a long- } \\
\text { term declining trajectory). }\end{array}$ & \\
\hline & France & $\begin{array}{l}\text { Sets out additional details on auction design } \\
\text { under a shipping ETS. In all other aspects, } \\
\text { the proposal is similar to the Norwegian ETS } \\
\text { proposal. }\end{array}$ & \\
\hline & \multicolumn{2}{|c|}{ (Grouping: In-Sector \& Out-of-Sector) } & \\
\hline $\begin{array}{l}\text { Penalty on trade } \\
\text { and development }\end{array}$ & Bahamas & $\begin{array}{l}\text { The imposition of any costs should be } \\
\text { proportionate to the contribution by } \\
\text { international shipping to global carbon } \\
\text { dioxide emissions. The reduction will apply } \\
\text { to individual ships and not member states, } \\
\text { and developing states will not be faced with a } \\
\text { penalty upon trade and development } \\
\text { (Grouping: Focus on In-Sector) }\end{array}$ & $\begin{array}{l}\text { MEPC 60/4/10, } \\
\text { GHG-WG 3/2 }\end{array}$ \\
\hline $\begin{array}{l}\text { Rebate } \\
\text { mechanism for a } \\
\text { market-based } \\
\text { instrument for } \\
\text { international } \\
\text { shipping }\end{array}$ & $\begin{array}{l}\text { IUCN (WWF } \\
\text { provides add-on } \\
\text { options) }\end{array}$ & $\begin{array}{l}\text { Compensate developing countries for the } \\
\text { financial impact of a MBM. It could be either } \\
\text { applied to any maritime MBM that generates } \\
\text { revenue (add-on option) or integrated with } \\
\text { the International Maritime Emission } \\
\text { Reduction Scheme (integrated option) } \\
\text { (Grouping: 'Focus on In-Sector' and 'In- } \\
\text { Sector \& Out-of-Sector' (add-on); In-Sector } \\
\text { and Out-of-Sector (integrated)) }\end{array}$ & $\begin{array}{l}\text { MEPC 60/4/55, } \\
\text { MEPC 61/5/33; } \\
\text { МЕPC 64/5/10, } \\
\text { МЕРC 64/5/12 }\end{array}$ \\
\hline
\end{tabular}

Source: The information in this table comes from the following texts: IMO, Main Events in IMO's Work on Limitation and Reduction of Greenhouse Gas Emissions from International Shipping (2011)

$<\mathrm{http} / / /$ www.imo.org/MediaCentre/resources/Pages/Greenhouse\%20gas\%20emissions.aspx>; Report of the Third Intersessional Meeting of the Working Group on Greenhouse Gas Emissions from Ships, Note by the Secretariat, MEPC $62^{\text {nd }}$ Session, Agenda Item 5, Doc MEPC 62/5/1 (8 April 2011) Annex 2.

\section{i. Environmental fee-related MBM proposals}

The GHG Fund, Port State Levy, and Penalty on Trade and Development are types of environmental fee-related MBM proposals. They provide the polluter with an incentive to reduce GHG emissions in order to pay less fees. Among the three proposals, the GHG Fund has received the most international attention. The Scientific Study on International Shipping 
and Market-Based Instruments asserts that all emissions covered by the GHG Fund will raise revenue for a central governing body, and the amount depends on the carbon price per tonne of carbon dioxide and on the amount of emissions. ${ }^{149}$ The higher carbon price generally indicates more reduction of carbon dioxide emissions. ${ }^{150}$ In this case, the carbon price, or the 'contribution,' is actually a levy on fuel since it has to be imposed on ships if these MBMs apply. ${ }^{151}$ In this way, the shipping GHG emissions could be reduced, and the revenues raised could be utilized to either compensate developing countries or reduce out-of-sector emissions through purchasing 'offsets.' Nevertheless, the utilization of revenues for reducing out-ofsector GHG emissions does not indicate that in-sector emission reduction is less significant. Rather, it is because the in-sector reduction can be achieved through the collection of a contribution or levy. ${ }^{152}$ Since shipowners generally respond to prices quickly, this proposal seems feasible and easy to implement. ${ }^{153}$ The main concern about this proposal lies in its dealing with revenue and how the special conditions of developing countries are taken into account. There might be another concern about the increased cost, including the extra administrative burden, associated with the GHG Fund proposal. The Feasibility Study and Impact Assessment Report, undertaken by the Expert Group and commissioned by the IMO, provides a comprehensive assessment of proposed MBMs. This report reveals that the increased cost for the GHG Fund is the lowest among the current MBM proposals except for the Penalty on Trade and Development proposed by the Bahamas. ${ }^{154}$

The Port State Levy proposed by Jamaica levies a uniform emissions charge on all vessels calling at ports, based on the amount of fuel consumed by the vessels on their voyage to that port. Technically, this option can be easily implemented and is consistent with the polluter pays principle due to its inclusion of all emissions produced by the ship during that journey. However, as mentioned earlier, this option might neither be accurate nor fair for all ships since it measures the ship's actual emissions solely by the fuels that have been consumed. This measurement ignores other pertinent parameters and, thus, is not conducted

\footnotetext{
${ }^{149}$ Scientific Study on International Shipping and Market-Based Instruments, IMO Doc. MEPC 60/INF.21 (15 January 2010) at 3. ${ }^{150}$ Ibid.

${ }^{151}$ Psaraftis, supra note 15 at 223.

152 Ibid.

${ }^{153}$ Ibid at 225.

${ }^{154}$ Full Report of the Work Undertaken by the Expert Group on Feasibility Study and Impact Assessment of Possible Market-based Measures, MEPC $61^{\text {st }}$ Session, Agenda Item 5, Doc MEPC 61/INF.2 (13 August 2010) at 14-16.
} 
in a 'cost-effective' manner. ${ }^{155}$ Meanwhile, since port states play a crucial role in the enforcement of this MBM, it is important to ensure that all port states, including those that choose not to participate in the system and those that lack proper monitoring and enforcement mechanisms, collaborate in implementing it. ${ }^{156}$ Otherwise, some ships may opt for routes through ports that lack monitoring and enforcement mechanisms to avoid the levy. This may lead to competitive distortion, distortion in trade flows, and a non-level playing field among shipping companies and ports. Additionally, under this scheme, the increased cost option is estimated to be the highest among current MBM options. ${ }^{157}$ At the sixty-fourth MEPC meeting, the International Chamber of Shipping (ICS) announced that its preferred MBM is a levy or compensation fund-based system and should directly relate to the actual fuel consumption of individual ships in service. ${ }^{158}$ This preference has also been followed by the shipping industries in some countries such as Greece and Korea. ${ }^{159}$

The penalty on trade and development proposal by the Bahamas aims to reduce shipping GHG emissions through the imposition of a penalty (cost) and insists that such costs should be proportionate to the GHG emissions from international shipping. To achieve this goal, it seeks to collect emission statistics from either the EEOI or ship funnels using a suitable sensor. According to the proposal, the ship is required to submit data to its flag state or recognized organization for annual verification. Under this scheme, no extra cost would be generated, but the main problem is that the EEOI is not available for all types of ships, and,

${ }^{155}$ Grouping and Evaluation of Proposed MBMs, submitted by Greece, Intersessional Meeting of the Working Group on GHG Emissions from Ships $3{ }^{\text {rd }}$ Session, Agenda Item 3, Doc GHG-WG 3/3 (24 February 2011) at para 44.

${ }^{156}$ Psaraftis, supra note 15 at 222.

${ }^{157}$ Full Report of the Work Undertaken by the Expert Group on Feasibility Study and Impact Assessment of Possible Market-based Measures, MEPC $61^{\text {st }}$ Session, Agenda Item 5, Doc MEPC 61/INF.2 (13 August 2010) at 14.

158 Operational Energy Efficiency of New and Existing Ships, submitted by the International Chamber of Shipping (ICS), MEPC $64^{\text {th }}$ Session, Agenda Item 5, Doc MEPC 64/5/11 (27 July 2012) at para 11.

${ }^{159}$ Union of Greek Shipowners, Prevention of Environmental Pollution by Ships: Regulation and Compensation Regimes and Industry Standards (2011) $<$ http://www.nee.gr/default.asp?t=anakoinoseisDetails\&id=13> at 29; George A Gratsos, Green and More Profitable Shipping (13 November 2012) $<$ http://www.nee.gr/downloads/183NEWSFRONT\%20NAFTILIAKI\%2013-1112.pdf $>$; Sang-Yoon Lee and Young-Tae Chang, 'Shipping Companies' Awareness and Preparedness for Greenhouse Gas Regulations: A Korean Case, in Theo Notteboom, ed, Current Issues in Shipping, Ports and Logistics, 25 at 44 (2011). 
currently, EEOI baselines are also 'impossible' to establish. ${ }^{160}$ The application of this proposal to the GHG issue will not be feasible if this problem cannot be resolved.

ii. Tradable permit scheme-related MBM proposals

Among the seven types of MBM proposals, the three types of global emissions trading systems (ETS) for international shipping submitted by Norway, the United Kingdom, and France are tradable permit scheme-related MBM proposals. The ETS mechanism was first regulated by the Kyoto Protocol and is currently utilized in the EU. As the world's largest company-level 'cap-and-trade' system, the EU ETS scheme has applied since 1 January 2005. As of 14 November 2012, all twenty-seven EU member states and three other European countries have participated in the scheme. ${ }^{161}$ Currently, there are only minor differences between the three ETS proposals for international shipping. Compared to the Norwegian ETS, the proposal by the United Kingdom has a different method of allocating emissions allowances and a different approach to setting the emissions cap, while the French proposal provides details on auction design. The main strength in relation to these ETSs lies in their higher certainty of carbon dioxide reduction. Although no international ETS has been implemented, a regional EU ETS might provide a 'prototype' from which international shipping can learn. ${ }^{162}$

There are significant challenges in implementing these ETS proposals for international shipping. First, significant carbon leakage and distortion of competition risks exist under the current ETS proposals. Carbon leakage generally refers to differentiated carbon policies and their subsequent impacts on GHG emissions. ${ }^{163}$ Since carbon leakage might hinder the success of a global GHG emissions reduction and thus distort global competition, it is important for the ETS to be applied to the international transportation sector, including international aviation, rather than solely to the shipping industry or even part of the shipping industry. ${ }^{164}$ The Norwegian ETS provides two exemptions from applying the scheme, namely ships below certain sizes and ships on international voyages to small

${ }^{160}$ Psaraftis, supra note 15 at 221.

161 These three states are Iceland, Liechtenstein and Norway. European Commission, Emissions Trading System (EU ETS), $<$ http://ec.europa.eu/clima/policies/ets/index_en.htm>.

162 Psaraftis, supra note 15 at 223.

${ }^{163}$ Larry Parker and John Blodgett, 'Carbon Leakage' and Trade: Issues and Approaches (19 December 2008), <http://www.fas.org/sgp/crs/misc/R40100.pdf>.

${ }^{164}$ Moffat, supra note 15 at 121. 
island developing states (SIDS). ${ }^{165}$ While it is a common practice within the IMO regime to set a threshold for ship size, the design of the voyage exemption was to meet the needs of developing countries. However, this regulation may also make it possible for some shipowners or ship operators to opt for certain ship sizes or certain shipping routes through the SIDS in order to get emission exemptions. In this case, competition will be distorted, and the reduction goal may also be hard to achieve. Second, compared with the GHG Fund proposal, an ETS incurs much higher administrative costs to track, monitor, and enforce as well as to avoid evasion and fraud. Last but not least, the current situation, in relation to the EU ETS generally, provides more uncertainty for the future development of an ETS for international shipping. As discussed earlier, the inclusion of the emissions from the international aviation industry into the EU ETS was suspended in December 2012, which, to some extent, makes the ETS less attractive for the shipping industry. Currently, international shipping organizations are generally against an ETS, whereas the shipping associations in some of the Annex I states to the UNFCCC support it. ${ }^{166}$

\section{iii. Hybrid MBM proposals}

Of the seven types of MBM proposals, the Efficiency Incentive Scheme, Ship Efficiency and Credit Trading, and Rebate Mechanism belong to the category of hybrid MBM proposals. The Efficiency Incentive Scheme and Ship Efficiency and Credit Trading can be regarded as hybrid MBMs with the EEDI as a benchmark, whereas the Rebate Mechanism is a hybrid MBM that can be built into any other MBM. One common feature between the Efficiency Incentive Scheme and Ship Efficiency and Credit Trading is that they both reward good performance ships in their own way, and the EEDI is used for measurement. However, it is the EEDI that makes the two hybrid MBM proposals less attractive. Two factors contribute to this argument. First, low EEDI indicates high energy efficiency, whereas a ship with a low

\footnotetext{
${ }^{165}$ A Further Outline of A Global Emission Trading System (ETS) for International Shipping, submitted by Norway, MEPC $60^{\text {th }}$ Session, Agenda Item 4, Doc MEPC 60/4/22 (15 January 2010) at 12, Annex 2.

${ }^{166}$ See, eg, the Round Table of International Shipping Associations, which opposed any emission trading system (ETS) in that it would be 'unworkable' for the shipping industry. Round Table of International Shipping Associations, supra note 47. The national shipowners associations in Australia, Belgium, Norway, Sweden, and the United Kingdom released a discussion paper in 2009 supporting a global cap-andtrade ETS to reduce GHG emissions from international shipping. ASA et al, supra note 145 .
} 
EEDI does not necessarily mean that it has the lowest GHG emissions. ${ }^{167}$ Its emissions might be more than those from a ship with a larger engine (high EEDI), which it needs to maintain certain speed to ensure safety in bad weather. ${ }^{168}$ In this case, the EEDI measurement does not work well. Second, the two hybrid MBM proposals, if adopted, will apply to both new ships and existing ships, whereas the EEDI adopted by Annex VI to the MARPOL Convention applies to new ships only. ${ }^{169}$ To date, there has been no research indicating the possible application of the EEDI to existing ships. After testing and verification, the International Association of Dry Cargo Shipowners asserts that the EEDI 'does not apply to, and hence it cannot and should not be used for, existing ships. ${ }^{170}$ Therefore, the adoption of these hybrid MBM proposals is not straightforward.

The Rebate Mechanism consists of two options: an add-on option by integrating with any revenue-raising MBM and an integrated option incorporated with the International Maritime Emission Reduction Scheme, which is a levy-on-fuel scheme. The main feature of this hybrid MBM is its compatibility with the CBDR principle. Under the add-on option, all ships pay for their emissions. However, a developing country obtains an annual rebate based on its share of global seaborne imports first, and then the remaining revenue from developed countries will be disbursed through the UNFCCC. In this way, the 'no net incidence' on developing countries can be ensured. ${ }^{171}$ In other words, developing countries will not suffer any loss, but they will benefit from participating in the Rebate Mechanism. The first draft of the legal text for the Rebate Mechanism was submitted to the sixty-fourth MEPC meeting by the World Wide Fund for Nature in October 2012, and it stipulates that 'each Party not included in annex II of the UNFCCC, or any successor annex, shall be eligible to an apportioned rebate [from a potential MBM Convention], and this rebate could be foregone as its contribution to international co-operation. ${ }^{172}$ This proposed regulation expands the scope of the beneficiaries of this scheme from SIDS and least developed countries as proposed by

\footnotetext{
${ }^{167}$ Psaraftis, supra note 15 at 222.

168 Ibid.

${ }^{169}$ MARPOL Convention, supra note 13, Annex VI (2011), Regulation 20-21.

${ }^{170}$ Application of the EEDI to Existing Ships, submitted by the International Association of Dry Cargo Shipowners, MEPC $63^{\text {rd }}$ Session, Agenda Item 5, Doc MEPC 63/5/12 (6 January 2012), summary.

${ }^{171}$ Ensuring No Net Incidence on Developing Countries from A Global Maritime MarketBased Mechanism, submitted by World Wide Fund for Nature (WWF), MEPC $63^{\text {rd }}$ Session, Agenda Item 5, Doc MEPC 63/5/6 (22 December 2011).

${ }^{172}$ Draft Legal Text on Uses of Financing Generated from A Maritime MBM, submitted by the WWF, MEPC $64^{\text {th }}$ Session, Agenda Item 5, Doc MEPC 64/5/10 (27 July 2012) at 5, Annex, Article 4.
} 
some countries to all non-Annex II states to the UNFCCC. It is expected that this mechanism will be attractive for developing countries due to its incorporation of the CBDR principle. Compared with other proposals, this proposal better reflects the interests of both developing countries and developed countries. Nevertheless, if the add-on option is built into any other MBM proposal, such as a GHG Fund or ETS, the administrative costs will probably be higher due to the possible increased number of administrative bodies. Therefore, it will be very challenging to control these costs. Furthermore, in terms of calculating a developing country's share of global imports by value, whether the available data are accurate and reliable, is another concern.

\section{CONCLUSION}

It has been a challenge for the international community to provide globally uniform regulations for reducing GHG emissions from international shipping that are acceptable to both developing countries and developed countries. Since the IMO has been mandated to regulate GHG emissions from international shipping, the challenge becomes whether both the CBDR and the NMFT principles can and should be applied to the issue under discussion. From an international law perspective, the IMO Convention and UNCLOS provide the IMO with general competence to regulate the GHG issue, while the Kyoto Protocol provides the IMO with a specific mandate to regulate this matter. These competences make it possible for the IMO to apply both principles in addressing GHG emissions from ships.

Recently, after a long-term deadlock, the IMO has partially regulated the GHG emissions by adopting mandatory technical and operational measures in its amendment of Annex VI to the MARPOL Convention. This regulation ensures significant emissions reduction and provides a strong incentive for the shipping industry to update cost-efficient technologies. However, the limited EEDI coverage and the lack of a SEEMP reduction target need to be addressed. In particular, the lack of full incorporation of the CBDR principle makes the future enforcement of this regulation questionable particularly for developing country fleets.

In furtherance of reducing GHG emissions from ships, the IMO has organized various discussions and negotiations on potential MBMs. Of the current seven types of MBMs proposed to the IMO, each of them has its pros and cons. Generally, the GHG Fund has low administrative costs and has been welcomed by most of the shipping industry, whereas the Rebate Mechanism serves as the only MBM that properly incorporates the CBDR principle. 
As a widely discussed option, an ETS has been opposed by the global shipping industry, but it has been supported by the shipping industry in some of the UNFCCC Annex I states. However, as all of these proposals are still under further development, it is important to ensure that the MBMs to be adopted should be cost-effective and take the interests of developing countries into account. 